\title{
Cultural Resources Investigations for the University of Texas Health Science Center at San Antonio Project, Bexar County,
} Texas

Sophia Salgado

Laura Clark

Follow this and additional works at: https://scholarworks.sfasu.edu/ita

Part of the American Material Culture Commons, Archaeological Anthropology Commons, Environmental Studies Commons, Other American Studies Commons, Other Arts and Humanities Commons, Other History of Art, Architecture, and Archaeology Commons, and the United States History Commons

Tell us how this article helped you.

This Article is brought to you for free and open access by the Center for Regional Heritage Research at SFA ScholarWorks. It has been accepted for inclusion in Index of Texas Archaeology: Open Access Gray Literature from the Lone Star State by an authorized editor of SFA ScholarWorks. For more information, please contact cdsscholarworks@sfasu.edu. 


\section{Cultural Resources Investigations for the University of Texas Health Science Center at San Antonio Project, Bexar County, Texas}

\section{Creative Commons License}

\section{(c) (1) (8)}

This work is licensed under a Creative Commons Attribution-NonCommercial 4.0 International License 


\section{CULTURAL RESOURCES INVESTIGATIONS FOR THE UNIVERSITY OF TEXAS HEALTH SCIENCE CENTER AT SAN ANTONIO PROJECT, BEXAR COUNTY, TEXAS}

ANTIQUITIES CODE OF TEXAS PERMIT NO. 9311

JUNE 2020

PREPARED FOR

TriLeaf Corporation

PREPARED BY

SWCA Environmental Consultants

Redacted 



\title{
CULTURAL RESOURCES INVESTIGATIONS FOR THE UNIVERSITY OF TEXAS HEALTH SCIENCE CENTER AT SAN ANTONIO PROJECT, BEXAR COUNTY, TEXAS
}

\author{
Prepared for \\ TriLeaf Corporation \\ 2550 S IH 35 \\ Suite 200 \\ Austin, Texas 78704 \\ Prepared by \\ Sophia Salgado \\ and \\ Laura Clark, M.A., RPA \\ Principal Investigator \\ Christina Nielsen, M.A
}

SWCA Environmental Consultants

4949 N Loop 1604 W

Suite 235

San Antonio, Texas 78249

www.swca.com

Antiquities Code of Texas Permit No. 9311

SWCA Project No. 60164

SWCA Cultural Resources Report No. 20-302

June 2020 



\section{ABSTRACT}

At the request of TriLeaf Corporation (TriLeaf), SWCA Environmental Consultants (SWCA) conducted a cultural resources investigation for the University of Texas Health Science Center at San Antonio (UTHSCSA) Project (Project) located in Bexar County, Texas. The Project involves the installation of a 432-foot-long (132-meter [m]-long) fiber-optic communication line directly south of Floyd Curl Drive in northwest San Antonio, Texas. The total disturbance of the proposed Project area measures approximately 0.28 acre ( 0.1 hectare [ha]) in size. The Project area is situated on the grounds of UTHSCSA and located approximately 8.48 miles (13.65 kilometers [km]) from downtown San Antonio. At its nearest, Zarzamora Creek is 40 feet $(12 \mathrm{~m})$ northwest of the Project area.

The proposed Project includes property owned by the UTHSCSA, a political subdivision of the state of Texas, and is therefore subject to review by the Texas Historical Commission (THC) under the Antiquities Code of Texas (ACT) and the City of San Antonio Office of Historic Preservation (SA-OHP) under the Historic Preservation and Design Sections of the City of San Antonio's Unified Development Code (UDC) (Article VI 35-606). SWCA conducted all work in accordance with the standards and guidelines set forth by the THC and the Council of Texas Archaeologists under ACT Permit No. 9311.

The purpose of the investigation was to identify and assess any cultural resources, such as historic and prehistoric archaeological sites and historic buildings, structures, objects, and sites (such as cemeteries) that might be located within the boundaries of the proposed Project area and evaluate the significance of these cultural resources. Investigations consisted of a background literature and historical map review and monitoring of mechanical trench excavations within the Project area. SWCA conducted all investigations in accordance with the standards and guidelines established by the THC and the Council of Texas Archeologists.

The background review determined that the Project area has not been previously surveyed for cultural resources, and three cultural resources investigations and three previously recorded cultural resources occurred within a 1.0-mile $(1.6-\mathrm{km})$ radius of the Project area. SWCA's intensive archaeological monitoring was performed during construction activities that occurred on April 7-14, 2020. All work within the Project area was conducted within moderately disturbed deposits. SWCA observed no subsurface cultural materials and no cultural features or temporally diagnostic artifacts were encountered.

In accordance with the City of San Antonio UDC and the ACT, SWCA has made a reasonable and good faith effort to identify cultural resources properties within the Project area. No properties were identified within the Project area that may meet the criteria for listing as a State Antiquities Landmark, nor as a Historic Landmark or District according to the UDC. Therefore, SWCA recommends that no additional cultural resources investigations are warranted within the UTHSCSA Project Area, as currently defined. Following the review and acceptance of the final cultural resources report, all records and photographs will be curated with the Center for Archaeological Research at the University of Texas at San Antonio, per requirements of the $\mathrm{ACT}$. 
Cultural Resources Investigations for the University of Texas Health Science Center at San Antonio Project, Bexar County, Texas

This page intentionally left blank. 


\section{CONTENTS}

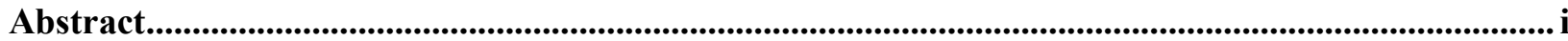

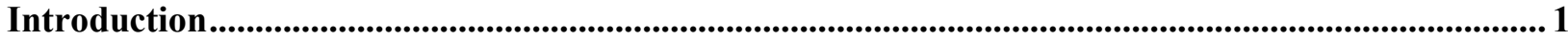

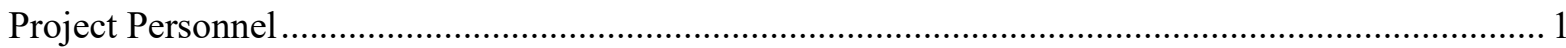

Project Area Description .......................................................................................................................... 1

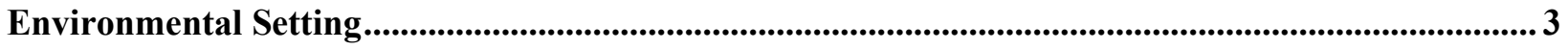

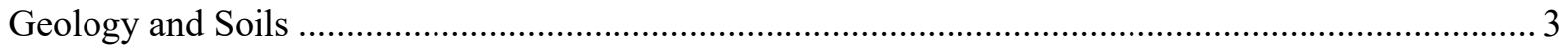

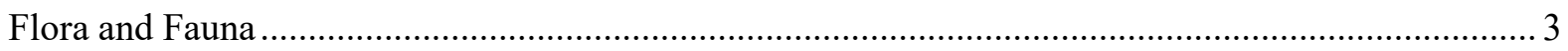

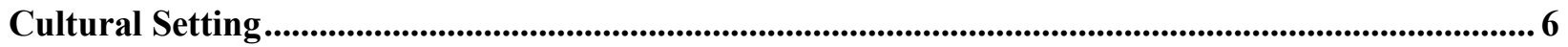

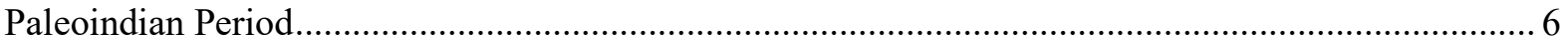

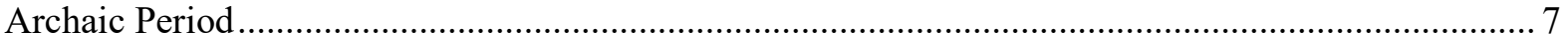

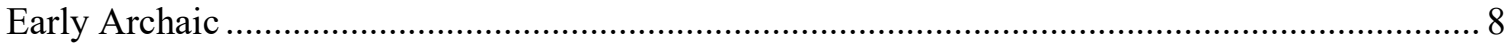

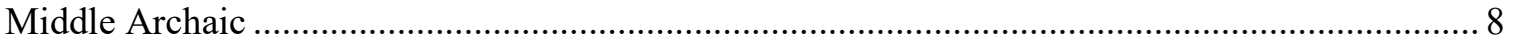

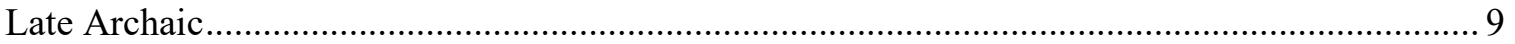

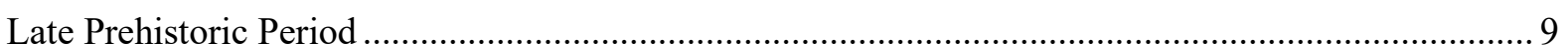

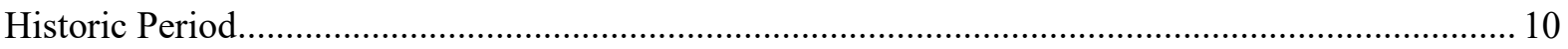

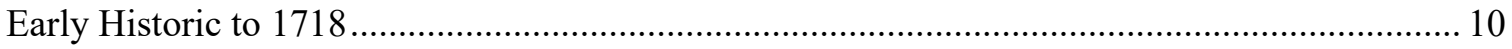

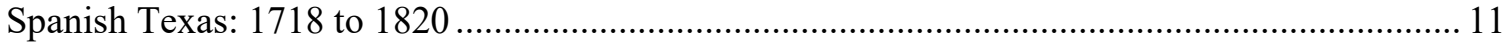

Texas Revolution, Independence, and Statehood: 1820 to 1848 ................................................ 11

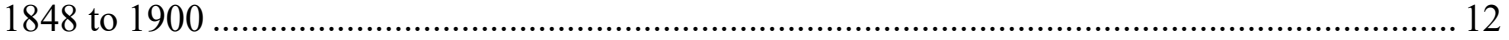

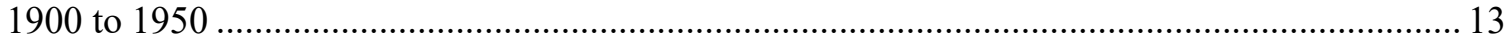

Background and Historic Map Review .............................................................................................................. 13

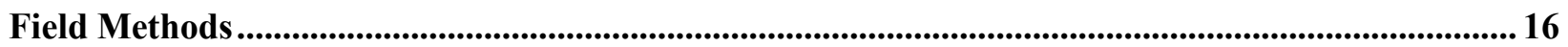

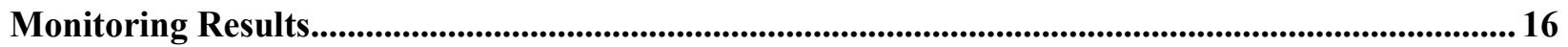

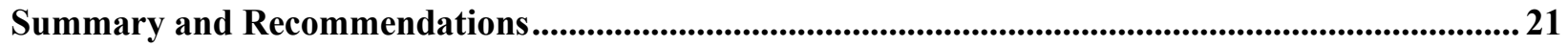

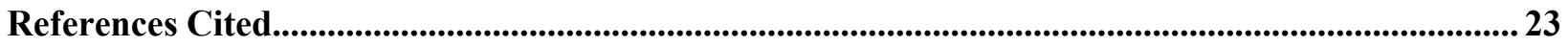




\section{Figures}

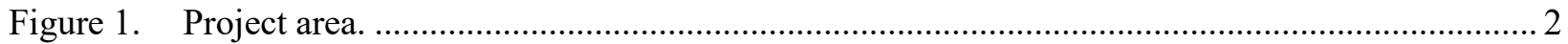

Figure 2. Project area aerial overview, geology map. ...................................................................... 4

Figure 3. Project area aerial overview, soils map...................................................................... 5

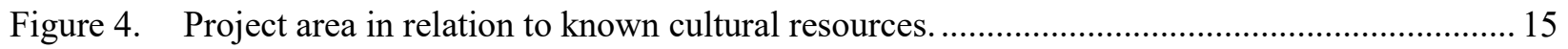

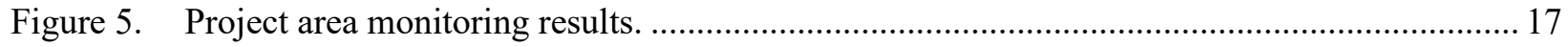

Figure 6. Overview of Zarzamora Creek in background identified by tall grasses, facing west............. 18

Figure 7. Overview of Project area locations of Trenches 5-7 prior to construction, view facing

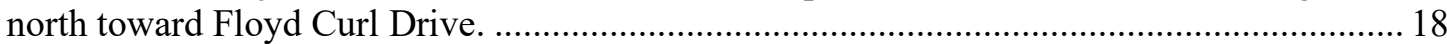

Figure 8. UTHSCSA building to right of frame and overview of Project area as well as locations of Trenches 1-4 prior to construction, view facing east...................................................... 19

Figure 9. Overview of excavation process within the Project area at Trench 1, view facing west......... 20

Figure 10. Overview of typical trench profile for Trenches 1-4 demonstrating shallow soil deposits within the southern portion of Project area at the intersection of Trench 3 and Trench 4, view facing north.

Figure 11. Overview of Trench 7 locale and surrounding disturbances within the Project area, view facing south.

Figure 12. Overview of typical trench profile for Trenches 5-7 locale demonstrating disturbed soil over basal clay within the northern portion of the Project area, view facing west.

\section{Tables}

Table 1. Previously Conducted Cultural Resource Investigations Within a 1-Mile Radius of the Project Area ..................................................................................................................... 14

Table 2. Previously Recorded Cultural Resources Within a 1-Mile Radius of the Project Area........... 16 


\section{INTRODUCTION}

At the request of TriLeaf Corporation (TriLeaf), SWCA Environmental Consultants (SWCA) conducted a cultural resources investigation for the University of Texas Health Science Center at San Antonio (UTHSCSA) Project (Project) located in northwest San Antonio, Bexar County, Texas (Figure 1). The Project involves the installation of a 432-foot-long (132-meter [m]-long) fiber-optic communication line directly south of Floyd Curl Drive, bounded by the UTHSCSA building to the south, a paved parking lot to the east, and Zarzamora Creek to the west. The total size of the proposed Project area is 0.28 acre $(0.1$ hectare [ha]). The proposed Project is located on land owned by the University of Texas, a political subdivision of the State of Texas, and is therefore subject to review by the Texas Historical Commission (THC) under the Antiquities Code of Texas (ACT) and is subject to review under the Historic Preservation and Design Sections of the Unified Development Code (UDC) (Article VI 35-630 to 35634).

The purpose of the investigation was to identify and assess any cultural resources, such as historic and prehistoric archaeological sites and historic buildings, structures, objects, and sites (such as cemeteries) that might be located within the boundaries of the proposed Project area and evaluate the significance of these cultural resources. Investigations consisted of a background literature and historical map review and the monitoring of mechanical trenching within the proposed Project area. SWCA conducted all investigations in accordance with the ACT and standards and guidelines established by the THC and the Council of Texas Archeologists (CTA). Following the review and acceptance of the final cultural resources report, all records and photographs will be curated with the Center for Archaeological Research at the University of Texas at San Antonio (CAR-UTSA), per requirements of the ACT in accordance with the CTA guidelines. The cultural resources investigation was conducted under ACT Permit No. 9311.

\section{Project Personnel}

Christina Nielsen, M.A., served as the Principal Investigator for the duration of the Project. Michael Retter, M.A., RPA, served as the Project Manager, overseeing overall logistics and organization, managing reporting, and agency consultation. The investigation was completed by archaeologist Paola Lopez from April 7 through 14, 2020. Laura Clark and Sophia Salgado prepared the report of the investigations. Jason Kainer expertly produced all field and report maps for the Project, and Joy Hengst provided technical editing and document preparation.

\section{PROJECT AREA DESCRIPTION}

The Project area appears on the Castle Hills, Texas (2998-311) U.S. Geological Survey (USGS) 7.5minute topographic quadrangle map (see Figure 1). The Project area is situated on the grounds of the UTHSCSA, immediately south of Floyd Curl Drive, and 500 feet $(153 \mathrm{~m})$ west of the intersection of Floyd Curl Drive and Sid Katz Drive in northwest San Antonio, Texas. The Project area is characterized as an urban setting surrounded by commercial and medical buildings, with a channelized segment of Zarzamora Creek within 50 feet $(15 \mathrm{~m})$ to the west-northwest (see Figure 1). SWCA understands the proposed Project involves the disturbance of 0.28 acre $(0.1 \mathrm{ha})$ of land directly south of Floyd Curl Drive in Bexar County, Texas. 


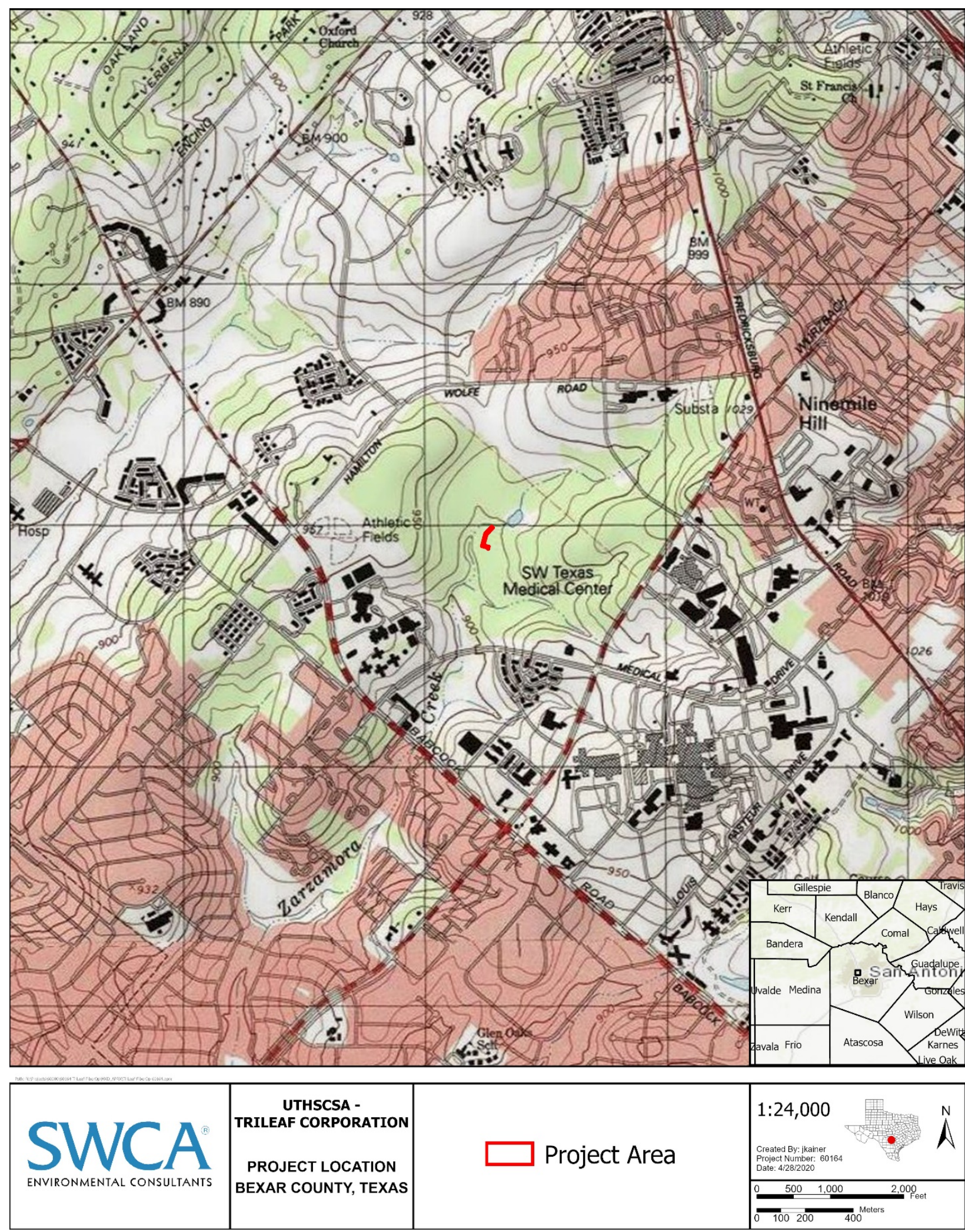

Figure 1. Project area. 


\section{ENVIRONMENTAL SETTING}

The Project area is situated within the Texas Blackland Prairies Level III Ecoregion and the Northern Blackland Prairie Level IV Ecoregion (Griffith et al. 2007). The Texas Blackland Prairie is a distinct physiographic region within the Gulf Coastal Plains.

\section{Geology and Soils}

The Project area is located in the Northern Blackland Prairie ecoregion of the Texas Blackland Prairie physiographic region (Griffith et al. 2007). The Texas Blackland Prairie is a distinct physiographic region within the Gulf Coastal Plains. The Blackland Prairie of the Gulf Coastal Plains is distinguishable by its fine-textured, clayey soils. The formation of the Blackland Prairie is attributed to the erosion of soils from the Edwards Plateau, which were deposited by a combination of eolian and colluvial processes (Black 1989). The Northern Blackland Prairie ecoregion is characterized by rolling to nearly level plains. Geologically, the entire Project area is underlain by the Pecan Gap Chalk (Kpg) dating to the Late Cretaceous age (Barnes et al. 1983) (Figure 2). According to the U.S. Department of Agriculture Natural Resources Conservation Service (NRCS) (2020), the Project area traverses only one soil type mapped as Houston Black gravelly clay soils (Figure 3). Houston Black gravelly clay soil series has 1 to 3 percent slopes and consists of very deep, moderately well drained, very slowly permeable soils that formed in clayey residuum derived from calcareous mudstone of Cretaceous Age (NRCS 2020).

\section{Flora and Fauna}

The Project area, located in a heavily urban landscape, has short to moderate grasses across most of the Project area and sporadic trees. The Project area is bounded by paved streets and parking lots. Regionally, the Project area is located along the southern extent of the Northern Blackland Prairie ecoregion and falls along the boundary of the Balconian and Tamaulipan biotic province (Blair 1950; Correll and Johnston 1979; Gould 1969; Griffith et al. 2007). Plants generally associated to this province include scrub brush consisting of mesquite, juniper, and cacti across pasturelands. The Blackland Prairie has a gently rolling topography that supports a diverse assemblage including southern hackberry (Celtis laevigata), cedar elm (Ulmus crassifolia), bur oak (Quercus macrocarpa), post oak (Quercus stellate), and blackjack oak (Quercus marilandica), with an understory of bunch grasses, shrubs, laurel greenbrier (family Lauraceae), yaupon holly (Ilex vomitoria), American beautyberry (Callicarpa Americana), and coralbean (Erythrina herbacea) (Kutac and Caran 1994; Petrides 1988; Simpson 1988). Originally the Blackland Prairie region supported a tall grass prairie (Gould 1969).

A wide variety of species of mammals, birds, reptiles, and amphibians occupy, or historically occupied, the Balconian and Tamaulipan biotic provinces. Their distribution and densities vary considerably and are mainly dependent upon the local vegetational community and available water resources. Small mammal species of these biotic zones include opossum (family Didelphidae), raccoon (Procyon sp.), nine-banded armadillo (Dasypus novemcinctus), deer mouse (Peromyscus sp.), pocket mouse (Perognathinae spp.), white-footed mouse (Peromyscus leucopus), southern plains woodrat (Neotoma micropus), desert cottontail (Sylvilagus audubonii), and black-tailed jackrabbit (Lepus californicus). Large mammal species that occur or have the potential to occur within the project area include white-tailed deer (Odocoileus virginianus) and javelina (family Tayassuidae) (Burt and Grossenheider 1976; Schmidly 1983). Less common are the predatory mammals including the coyote (Canis latrans), bobcat (Lynx rufus), and gray fox (Urocyon cinereoargenteus). In addition, bison (Bison bison), mountain lion (Puma concolor), and black bear (Ursus americanus) would have been present prehistorically (Davis and Schmidly 1994). 


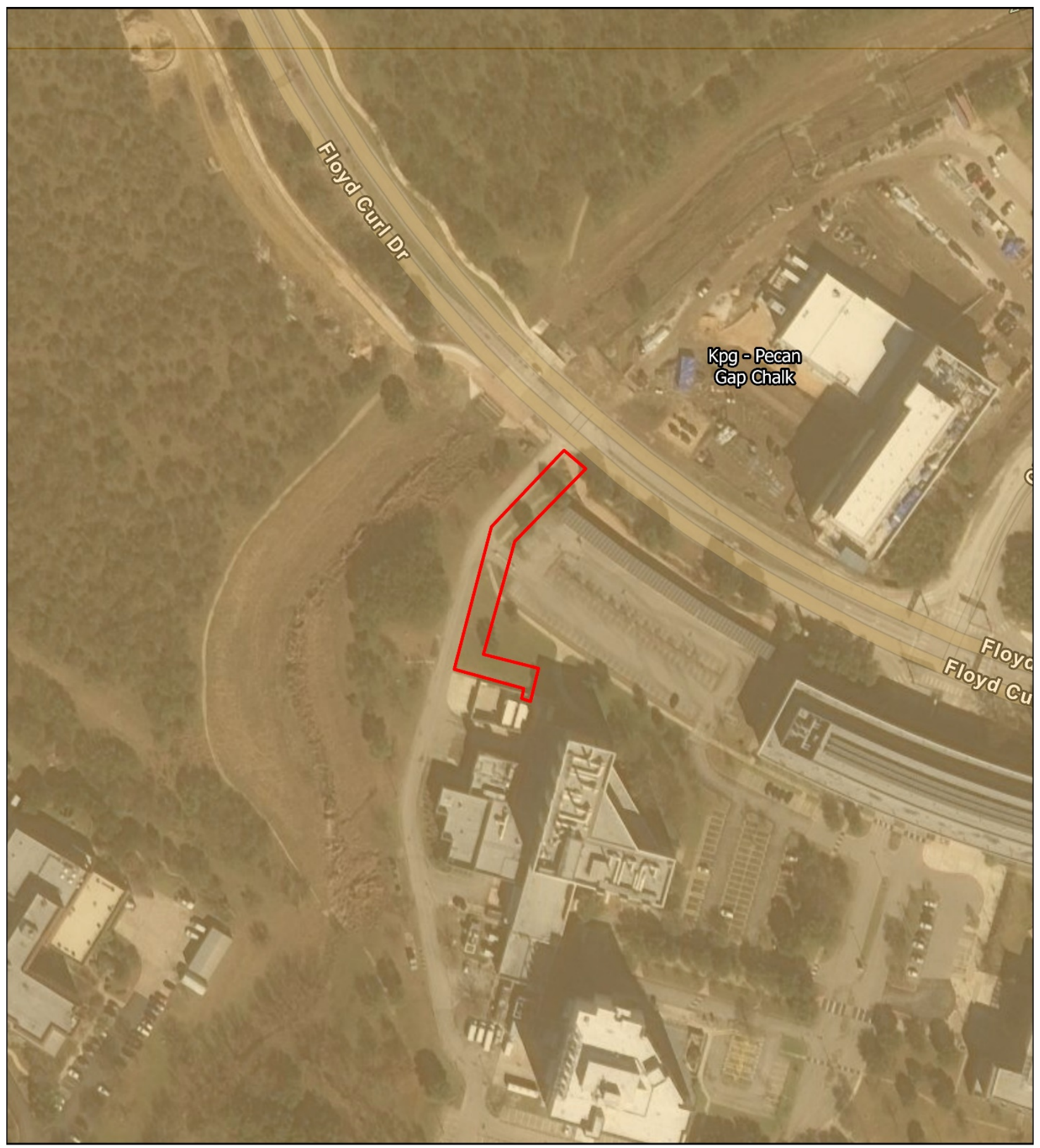

\begin{tabular}{|c|c|c|c|}
\hline 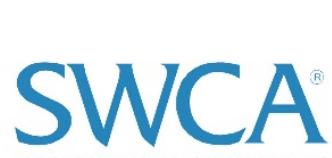 & $\begin{array}{c}\text { UTHSCSA - } \\
\text { TRILEAF CORPORATION } \\
\text { GEOLOGY MAP }\end{array}$ & Project Area & $1: 2,400$ \\
\hline ENVIRONMENTAL CONSULTANTS & BEXAR COUNTY, TEXAS & & 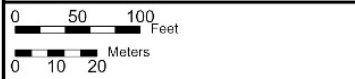 \\
\hline
\end{tabular}

Figure 2. Project area aerial overview, geology map. 
Cultural Resources Investigations for the University of Texas Health Science Center at San Antonio Project, Bexar County, Texas

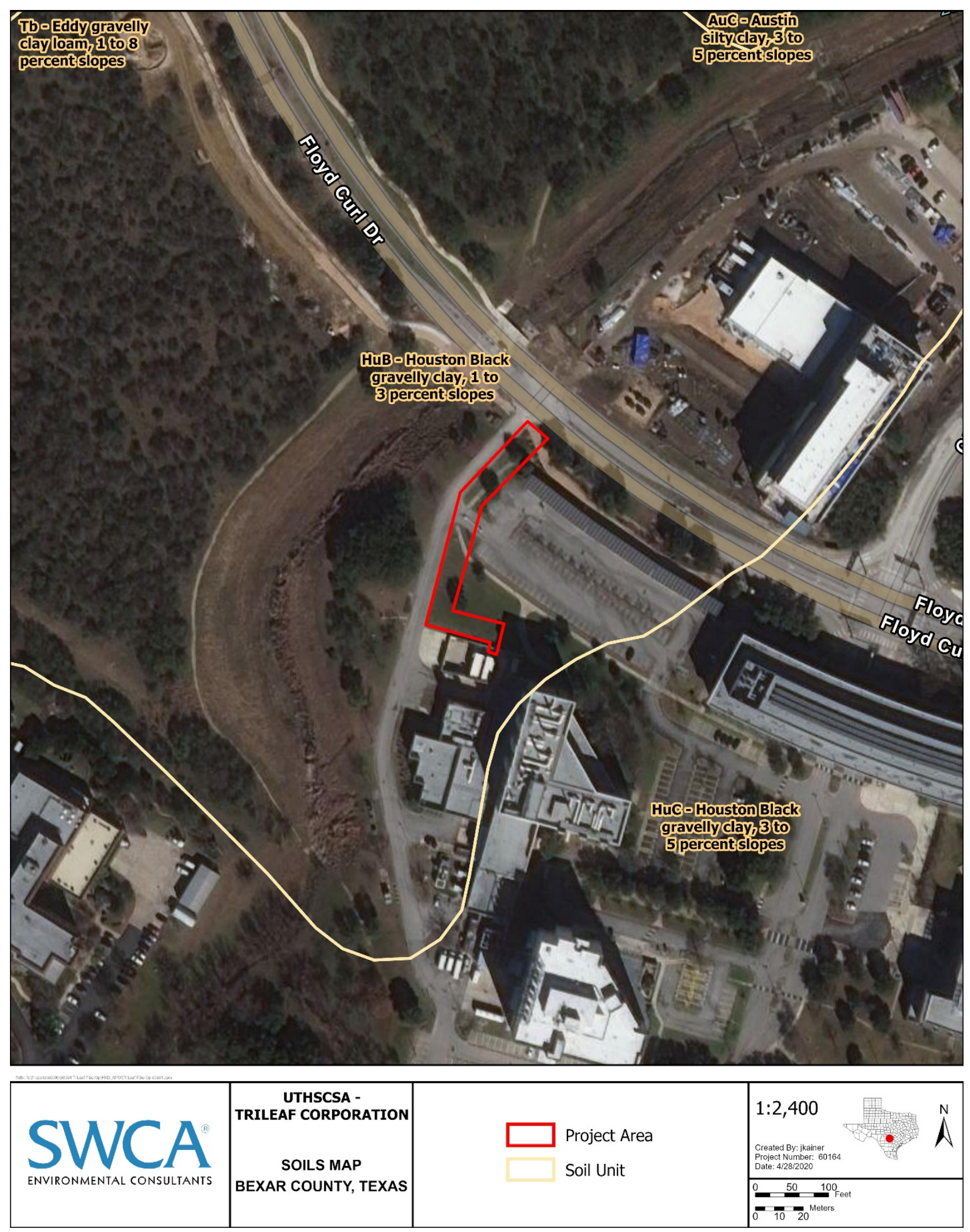

Figure 3. Project area aerial overview, soils map. 
Bird species composition in the Balconian biotic zone is fairly diverse with numerous breeding, migrant, and wintering species present (Kutac and Caran 1994). Bird species present in the Tamaulipan biotic region are typical of the brush and scrub vegetational community. Common species found in these areas include northern cardinal (Cardinalis cardinalis), tufted titmouse (Baeolophus bicolor), Bewick's wren (Thryomanes bewickii), mourning dove (Zenaida macroura), northern mockingbird (Mimus polyglottos), red-tailed hawk (Buteo jamaicensis), wild turkey (Meleagris gallopavo), turkey vulture (Cathartes aura), house sparrow (Passer domesticus), olive sparrow (Arremonops rufivirgatus), the northern bobwhite (Colinus virginianus), and the long-billed thrasher (Toxostoma longirostre) (Davis and Schmidly 1994; Kutac and Caran 1994).

Amphibians and reptiles within these provinces include the ornate box turtle (Terrapene ornata ornata), Texas banded gecko (Coleonyx brevis), tree lizard (Urosaurus sp.), eastern grass lizard (Ophisaurus ventralis), smallmouth salamander (Ambystoma texanum), Blanchard's cricket frog (Acris blanchardi), eastern green toad (Bufo debilis), Texas toad (Anaxyrus speciosus), common musk turtle (Sternotherus odoratus), Guadalupe spiny softshell (Apalone spinifera guadalupensis), black-tailed rattlesnake (Crotalus molossus), western diamondback rattlesnake (Crotalus atrox), northern copperhead (Agkistrodon contortrix mokasen), checkered garter snake (Thamnophis marcianus), eastern yellowbelly racer (Coluber constrictor flaviventris), Great Plains rat snake (Pantherophis emoryi), Texas rat snake (Elaphe obsoleta lindheimeri), Texas coral snake (Micrurus tener), broad banded copperhead (Agkistrodon contortrix laticinctus), and the western cottonmouth (Agkistrodon piscivorus leucostoma) (Conant and Collins 1998; Kutac and Caran 1994).

\section{CULTURAL SETTING}

The Project area lies at the intersection of two archaeological regions, the Central Texas Region and South Texas Region. These regions are recent analytical constructs, but they do contain a measure of distinct, spatial, cultural information (see Prewitt 1981; Collins 2004). In this study, the Project area is included with the Central Texas Archeological Region.

Following Collins (2004), the archaeological periods in Central and South Texas are Paleoindian, Archaic, Prehistoric, and Historic. Subperiods of the Paleoindian period are Early and Late. The Archaic subperiods are Early, Middle, and Late Archaic. The date ranges for archaeological periods uses radiocarbon years B.P., following the convention of Collins (1995). Within the San Antonio area are significant archaeological deposits representing all archaeological periods. Significant archaeological sites include the Richard Beene site (i.e., 41BX831), which contained discrete Early Archaic deposits of Angostura and split-stemmed points (Thoms et al. 1996), and the Pavo Real site (i.e., 41BX52), which contains Early Paleoindian Clovis and Folsom deposits (Collins et al. 2003).

The Historic period begins with the first European documentation from the exploits of Cabeza de Vaca in the 1530s. Further exploration and conquest of Texas by the Spanish occurred, in part, because of accounts of fabled riches suggested by de Vaca, and the expectations of riches fueled by earlier conquests of Mexico and Peru. The Historic period is divided into eras corresponding to political and social change.

\section{Paleoindian Period}

Paleoindian sites occur in a variety of topographic settings and include both surface and deeply buried sites, rockshelter sites, and isolated artifacts spanning over 2,500 years of occupations (ca. 11,500-8800 B.P.) in the Central Texas region (Collins 2004:116). The period is often described as having been characterized by small but highly mobile bands of foragers who were specialized hunters of Pleistocene megafauna. But Paleoindians probably used a much wider array of resources (Meltzer and Bever 
1995:59), including small fauna and plant foods. Faunal remains from Kincaid Rockshelter (i.e., 41UV2) and the Wilson-Leonard site (i.e., 41WM235) support this view (Bousman 1998; Bousman et al. 2004; Collins 1998; Collins et al. 1989).

Collins $(1995,2004)$ divides the Paleoindian period into early and late subperiods. Two main projectile point styles, Clovis and Folsom, are included in the early subperiod. A third type, Plainview, may be contemporary with Folsom. Clovis chipped stone artifact assemblages, including the diagnostic fluted lanceolate Clovis point, were produced by bifacial, flake, and prismatic-blade techniques on high-quality and oftentimes exotic lithic materials (Collins 1990). Along with chipped stone artifacts, Clovis assemblages include engraved stones, bone and ivory points, stone bolas, and ochre (Collins 2004:116; Collins et al. 1992). Clovis points are found evenly distributed along the eastern edge of the Edwards Plateau, where the presence of springs and outcrops of chert-bearing limestone are common (Meltzer and Bever 1995:58). Analyses of Clovis artifacts and site types suggest that Clovis peoples were welladapted, generalized hunter-gatherers with the technology to hunt larger game but not solely rely on it.

In contrast, Folsom tool kits - consisting of fluted Folsom points, thin unfluted (Midland) points, large thin bifaces, and end scrapers - are more indicative of specialized hunting, particularly of bison (Collins 2004:117). Folsom points have been recovered from Kincaid Rockshelter (Collins et al. 1989) and Pavo Real (Collins et al. 2003). Folsom point distributions, both the frequency and spatial patterning, differ from the Clovis patterns, suggesting a shift in adaptation patterns (Bever and Meltzer 2007; Meltzer and Bever 1995:60 and 74).

Postdating Clovis and Folsom points in the archaeological record are a series of dart point styles (primarily unfluted lanceolate darts) for which the temporal, technological, or cultural significance is unclear. Often, the Plainview type name is assigned these dart points, but Collins (2004:117) has noted that many of these points typed as Plainview do not parallel Plainview type-site points in thinness and flaking technology. At Wilson-Leonard, the Paleoindian projectile point sequence includes an expandingstem dart point termed Wilson, which dates to ca. 10,000-9500 B.P. Postdating the Wilson component is a series of unfluted lanceolate points referred to as Golondrina-Barber, St. Mary's Hall, and Angostura, but their chronological sequence is poorly understood.

By the Late Paleoindian subperiod, aspects of Archaic lifeways became increasingly entrenched, and in many ways, the Late Paleoindian subperiod is a transition between the early Paleoindian and succeeding Archaic periods (Collins 2004:118). During this period there is evidence of a diverse subsistence practice, a variety of lithic tools and ritualized burial practices (Bousman 1998; Bousman et al. 2004).

\section{Archaic Period}

The longest period is the Archaic, beginning between 8800 B.P. and 8000 B.P. and extending until approximately 1200 B.P. when the widespread use of the bow and arrow occurs. Collins $(1995,2004)$ and Collins et al. (1998) use 8800 B.P. as the approximate starting date for the Early Archaic where there is a shift toward hunting and gathering of a wider array of animal and plant resources and a decrease in group mobility (Willey and Phillips 1958:107-108).

In the eastern and southwestern United States and on the Great Plains, development of horticulturalbased, semi-sedentary to sedentary societies succeeds the Archaic period. In these areas, the Archaic truly represents a developmental stage of adaptation as Willey and Phillips (1958) define it. For central Texas, this manifestation of the Archaic is somewhat problematic. An increasing amount of evidence suggests that Archaic-like adaptations were in place before the Archaic (see Collins 1998, 2004:118; Collins et al. 1989) and these practices continued into the succeeding Late Prehistoric period (Collins 1995:385; Prewitt 1981:74). 


\section{Early Archaic}

The use of 8800 B.P. as a beginning date for the Early Archaic appears to be at the extreme older date range. It is just as probable that the date is closer to 8000 B.P., which is closer to the beginning date of the Early Archaic for South Texas, according to Hester (2004).

Early Archaic (8800-6000 B.P.) lithic assemblages can be diverse, with a greater variety of stone tool types than during the previous Paleoindian period (Weir 1976:115-122), suggesting that populations were highly mobile and population densities were probably low (Houk et al. 2008). It has been noted that there is a concentration of Early Archaic sites along the eastern and southern margins of the Edwards Plateau (Johnson and Goode 1994; McKinney 1981; Story 1985). This distribution may indicate drier and/or more extreme climatic conditions at the time, given that these environments have more reliable water sources and a more diverse resource base than other parts of the region. Early Archaic projectile point styles include Hoxie, Gower, Wells, Martindale, and Uvalde. Clear Fork and Guadalupe bifaces and a variety of other bifacial and unifacial tools are common to Early Archaic assemblages. The increasing regional variation in tool styles also suggests increasing territorialism that reduced exchanges of technology and interaction between distant and possibly local groups (Oksanen 2008).

Construction and use of rock hearths and ovens, which had been limited during late Paleoindian times, became commonplace. Such a practice probably was related to cooking plant foods, particularly roots and bulbs, many of which must be subjected to prolonged periods of cooking to render them consumable and digestible (Black et al. 1997:257; Wandsnider 1997; Wilson 1930).

Significant Early Archaic sites include the Richard Beene site in Bexar County (Thoms and Mandel 1992), the Gatlin site in Kerr County (Houk et al. 2008), Wilson-Leonard (Collins et al. 1998), the Icehouse site (i.e., 41HY161) in San Marcos (Oksanen 2008) and the Youngsport site in Bell County (Shafer 1963). The end of the Early Archaic is a poorly documented transition. The convention of 6000 B.P. intends to mark the appearance of both a changing environment and the appearance of specialized technology associated with bison hunting.

\section{Middle Archaic}

During the Middle Archaic period (6000-4000 B.P.), the number and distribution of sites, as well as their size, probably increased as population densities grew (Prewitt 1981:73; Weir 1976:124, 135).

Macrobands may have formed at least seasonally, or more small groups may have used the same sites for longer periods (Weir 1976:130-131). Development of burned rock middens toward the end of the Middle Archaic suggest a greater reliance on plant foods, although tool kits still imply a considerable dependence on hunting (Prewitt 1985:222-226). Middle Archaic projectile point styles include Bell, Andice, Taylor, Baird, Nolan, and Travis. Bell and Andice points reflect a shift in lithic technology from the preceding Early Archaic Martindale and Uvalde point styles (Collins 2004:119). Johnson and Goode (1994:25) suggest that the Bell and Andice darts are parts of a specialized bison-hunting tool kit. They also believe that an influx of bison and bison-hunting groups from the Eastern Woodland margins during a slightly more mesic period marked the beginning of the Middle Archaic.

Although no bison remains were detected, Bell and Andice points were recovered from the Cibolo Crossing (Kibler and Scott 2000), Panther Springs Creek, and Granberg II (Black and McGraw 1985) sites in Bexar County. Bison were either absent or decreased drastically in number as more-xeric conditions returned during the late part of the Middle Archaic. Later Middle Archaic projectile point styles represent another shift in lithic technology (Collins 2004:120; Johnson and Goode 1994:27). At the same time, a shift to more-xeric conditions saw the burned rock middens develop, probably because intensified use of a specific resource (geophytic or xerophytic plants) or resource patches meant the debris 
of multiple rock ovens and hearths accumulated as middens on stable to slowly aggrading surfaces, as Kelley and Campbell (1942) suggested many years ago. Johnson and Goode (1994:26) believe that the dry conditions promoted the spread of yuccas and sotols, and that it was these plants that Middle Archaic peoples collected and cooked in large rock ovens.

\section{Late Archaic}

During the succeeding Late Archaic period (4000 to 1300-1200 B.P.), populations continued to increase (Prewitt 1985:217). Within stratified Archaic sites such as Loeve-Fox, Cibolo Crossing, and Panther Springs Creek, the Late Archaic components contain the densest concentrations of cultural materials. Establishment of large cemeteries along drainages suggests certain groups had strong territorial ties (Story 1985:40). A variety of projectile point styles appeared throughout the Late Archaic period. Middle Archaic subsistence technology, including the use of rock and earth ovens, continued into the Late Archaic period. Collins (2004:121) states that, at the beginning of the Late Archaic period, the use of rock ovens and the resultant formation of burned rock middens reached its zenith and that the use of rock and earth ovens declined during the latter half of the Late Archaic. There is, however, mounting chronological data that midden formation culminated much later and that this high level of rock and earth oven use continued into the early Late Prehistoric period (Black et al. 1997:270-284; Kleinbach et al. 1995:795).

The use of rock and earth ovens (and the formation of burned rock middens) for processing and cooking plant foods suggests that this technology was part of a generalized foraging strategy. However, at times during the Late Archaic, this generalized foraging strategy appears to have been marked by shifts to a specialized economy focused on bison hunting (Kibler and Scott 2000:125-137). Castroville, Montell, and Marcos dart points are elements of tool kits often associated with bison hunting (Collins 1968). Archaeological evidence of this association is seen at Bonfire Shelter in Val Verde County (Dibble and Lorrain 1968), Jonas Terrace (Johnson 1995), Oblate Rockshelter (Johnson et al. 1962:116), John Ischy (Sorrow 1969), and Panther Springs Creek (Black and McGraw 1985).

The Archaic period represents a hunting and gathering way of life that was successful and that remained virtually unchanged for more than 7,500 years. This notion is based in part on fairly consistent artifact and tool assemblages through time and place and on resource patches that were used continually for several millennia, as the formation of burned rock middens shows. This pattern of generalized foraging, though marked by brief shifts to a heavy reliance on bison, continued almost unchanged into the succeeding Late Prehistoric period.

\section{Late Prehistoric Period}

Introduction of the bow and arrow and, later, ceramics into Central Texas marked the Late Prehistoric period. Population densities dropped considerably from their Late Archaic peak (Prewitt 1985:217). Subsistence strategies did not differ greatly from the preceding period, although bison again became an important economic resource during the late part of the Late Prehistoric period (Prewitt 1981:74). Use of rock and earth ovens for plant food processing and the subsequent development of burned rock middens continued throughout the Late Prehistoric period (Black et al. 1997; Kleinbach et al. 1995:795). Horticulture came into play very late in the region but was of minor importance to overall subsistence strategies (Collins 2004:122).

In central Texas, the Late Prehistoric period generally is associated with the Austin and Toyah phases (Jelks 1962; Prewitt 1981:82-84). Austin and Toyah phase horizon markers, Scallorn-Edwards and Perdiz arrow points, respectively, are distributed across most of the state. Violence and conflict often marked introduction of Scallorn and Edwards arrow points into central Texas-many excavated burials contain these point tips in contexts indicating they were the cause of death (Prewitt 1981:83). Subsistence 
strategies and technologies (other than arrow points) did not change much from the preceding Late Archaic period. Prewitt's (1981) use of the term "Neoarchaic" recognizes this continuity. In fact, Johnson and Goode (1994:39-40) and Collins (2004:122) state that the break between the Austin and Toyah phases could easily and appropriately represent the break between the Late Archaic and the Late Prehistoric.

Around 1000-750 B.P., slightly more-xeric climatic conditions returned to the region, and bison came back in large numbers (Huebner 1991; Toomey et al. 1993). Using this vast resource, Toyah peoples were equipped with Perdiz point-tipped arrows, end scrapers, four-beveled-edge knives, and plain bonetempered ceramics. Toyah technology and subsistence strategies represent a completely different tradition from the preceding Austin phase. Collins (1995:388) states that formation of burned rock middens ceased as bison hunting and group mobility obtained a level of importance not witnessed since Folsom times. Although the importance of bison hunting and high group mobility hardly can be disputed, the argument that burned rock midden development ceased during the Toyah phase is tenuous. Black et al. (1997) claim that burned rock midden formation, although not as prevalent as in earlier periods, was part of the adaptive strategies of Toyah peoples.

\section{Historic Period}

The historic period in Texas begins in 1528 near Galveston Island with the encounter between the Pánfilo de Narváez expedition and a Karankawa group. After disaster befell the expedition, one of the members, Cabeza de Vaca, spent six years of wandering through Texas in the 1530s. Cabeza de Vaca traversed coastal Texas and parts of the interior and recounted in great ethnographic detail the peoples he encountered (Chipman 1992). Based in part from his exploits and suggestions of a kingdom of gold, the Coronado expedition was formed to search for a "northern" Cuzco or Teotihuacan, and by 1540 it crossed into New Mexico, and into Texas (Fehrenbach 1978).

The following historic discussion focuses on the San Antonio region and the significance of this region during the historic period and the creation of Texas independence, sovereignty, and statehood.

\section{Early Historic to 1718}

The Native Americans living in the missions along the San Antonio River were referred to by the Spanish as "Coahuiltecans." The name comes from a southern tribe named after the Spanish province of "Coahuila," which later became a Mexican state. The term "Coahuiltecan" is a generalized term and makes no distinction between language and cultural differences of the tribes living in the area. The abundant berries, nuts, and fish made San Pedro Springs an attractive place to camp and/or live (Johnston 1947; Ramsdell 1968).

The San Antonio area was first explored in 1691 by the Governor of the Spanish Province of Texas, Domingo Terán de los Ríos, and Father Damián Massenet. The pair traveled to San Pedro Springs where they encountered a hunter-gather tribe named Payaya. In their village named Yanaguana, the Payaya lived in simple huts made of brushwood and grass. The river and village were renamed after San Antonio de Padua by Terán and Massenet (Johnston 1947).

Further Spanish exploration was conducted in 1709 by Father Antonio de San Buenaventura y Olivares. Father Olivares was the first to express interest in setting up a mission in the San Antonio area (Jasinski 2020; Johnston 1947). 


\section{Spanish Texas: 1718 to 1820}

San Antonio de Béxar Presidio, located on the east bank of the San Antonio River, was founded in 1718. In the same year, Mission San Antonio de Valero, later known as the Alamo, was transferred from the Rio Grande by Father Olivares. This mission was named after St. Anthony of Padua and the Marquis de Valero, the Viceroy of New Spain. The church was originally constructed of adobe and the huts of wood and thatch (Johnston 1947; Schoelwer 2020).

La Villita, an Indian village about 1,500 feet south of the Alamo, was built around 1722. The Indians from the Mission San Antonio de Valero lived in La Villita in crude huts called "jacales" (Johnston 1947:31). Jacales were typically constructed with an upright line of poles sunk into a footing ditch and then woven horizontally with smaller sticks. The walls were subsequently covered with adobe. Later, La Villita served as a home to the families of soldiers who protected the mission. (Johnston 1947).

The villa of San Fernando de Béxar was founded in 1731 by the Canary Islanders. The Canary Islanders were a small group, totaling 56 people, sent by Spain to colonize the province of Texas. Under the leadership of Juan Leal Goraz, the village of San Fernando de Béxar was founded near the Presidio de Béxar and the first civil government in Texas was formed (Butterfield 1968; Ramsdell 1968).

In 1773, San Antonio de Béxar became the capital of Spanish Texas. By 1790, most of the Indians living in San Antonio had either already abandoned the missions or died from diseases like smallpox and the measles brought in by Europeans. Mission San Antonio de Valero was secularized in 1794 and mission land, excluding the church and convent, was divided amongst the few Indians that remained in the area (Johnston 1947).

Spain and Mexican revolutionists fought over San Antonio throughout the early 1800s. The Casas revolt of 1811 ended with the assertion of power by the Spanish regime. Captain Juan Bautista de las Casas went against the Spanish authority and was arrested and sent to Mexico. In Monclova, he was tried and found guilty of treason and shot to death. His head was sent back to San Antonio as a sign of defeat (Caldwell 2020; Ramsdell 1968).

San Antonio declared for Mexican independence in 1813 but was recaptured by Royalist forces in the battles of Alazán Creek and Medina. During this period of unrest, conditions in Texas were becoming worse. Inadequate provisions and neglected agricultural fields along with the fear of political and military upheavals forced many Texans to abandon their homes and move elsewhere (Jasinski 2020; Heusinger 1951).

\section{Texas Revolution, Independence, and Statehood: 1820 to 1848}

During the Texas Revolution, San Antonio was the site of several battles, including the siege of Bexar and the battle of the Alamo (Jasinski 2020).

General Martín Perfecto de Cós, along with 650 men, fortified the plaza of San Antonio de Béxar west of the San Antonio River and the Alamo to the east. Texan volunteers arrived in San Antonio on October 12, 1835 to set up camp. Upon hearing the Mexican army's morale and rations were low, a council was held to decide whether to attack. Commanding Officer Edward Burleson and most of the other officers voted to end the siege. One man spoke up and asked, "Who will go with Old Ben Milam into San Antonio?" (House 1949:47). Approximately 300 men joined Milam and the battle finally began on December 5, 1835. General Cós focused his troops at the Alamo but was unsuccessful in holding San Antonio. By the morning of December 9, 1835, Cós surrendered (Barr 2020; House 1949). 
The Alamo Garrison had been acquired following the defeat of Mexican General Martin Perfecto de Cós' army in the December 1835 Battle of San Antonio. The subsequent formation of the Matamoros Expedition cost the Alamo much-needed supplies and men. This expedition was created with the intentions of invading Mexico through the city of Matamoros; however, the plan was never executed due to political turmoil in the Texas government. Some relief came over the next few months with the arrivals of Col. Jim Bowie, Col. William B. Travis, and David Crockett; each bringing 12 to 30 additional men. Rumors of the approaching Mexican army of nearly 2,000 men soon followed (Hatch 1999).

General Santa Anna arrived in San Antonio with between 1,800 and 2,100 men on February 23, 1836. Upon their arrival, Col. Travis ordered his men to retreat into the Alamo (Hatch 1999). Gen. Santa Anna raised a red flag signifying "no quarter-no mercy" and received a cannon shot from the Texians in defiance (Hatch 1999:20). Another defiant cannon is rumored to have been shot in response to a request for an unconditional surrender. In a letter sent February 24, 1836, addressed to the "People of Texas and all Americans in the World," Col. Travis pleas for assistance and states "if this call is neglected, I am determined to sustain myself as long as possible \& die like a soldier who never forgets what is due his own honor \& that of his country. Victory or Death" (Groneman 2001:6).

Over the next few days the Alamo defenders suffered shortages of provisions and water, constant bombardment on the Alamo, and psychological warfare through the nights ordered by Gen. Santa Anna. On the third day of the siege, Mexican troops created a diversion at the Alamo's main gate in an attempt to cross the San Antonio River and reach the south wall of the Alamo through La Villita. The Texians repelled both attacks and subsequently burned buildings in close proximity to the Alamo to deny shelter for Santa Anna's men in La Villita (Hatch 1999). Gen. Santa Anna ordered many small attacks in an attempt to breach the Alamo's walls. Many Mexicans lost their lives in the process; however, no Texians were killed in the 12-day siege before the final battle (Hatch 1999; Huffines 1999).

On March 4, Gen. Santa Anna held a Council of War to decide plans of attack and the fate of prisoners. The final decision to attack the Alamo with full force was made the following day, March 5, 1836 (Hatch 1999). The Mexican army moved into position just after midnight on March 6 and waited for the signal to attack. This call came around 5 o'clock in the morning when a soldier cried out "Viva Santa Anna!" (Huffines 1999:134). With the element of surprise lost, Santa Anna ordered his troops to begin the attack on the Alamo garrison (Huffines 1999).

The vicious battle, lasting only 90 minutes, left every Texian combatant dead. The number of Mexican dead is a matter of debate, with numbers ranging from 100 to 1,600; uncounted more were wounded. The Texian's bodies were burned on funeral pyres on either side of the Alameda. Santa Anna won the battle at the Alamo but victory and independence was won by the Texans two weeks later in the Battle of San Jacinto (Hatch 1999; Huffines 1999).

After Mexican forces were removed from San Antonio in December of 1836, the Republic of Texas began organizing Bexar County. The next month, San Antonio was chartered as the county seat. Despite these progressions, many conflicts continued to occur in San Antonio including the Council House Fight of 1840 and two Mexican invasions in 1842 (Jasinski 2020).

\section{8 to 1900}

After Texas entered the Union in 1845, San Antonio's already diverse population grew dramatically. The Irish came to Texas in the late 1830s to early 1840s and established "Irish Flat." Germans settled in San Antonio in the 1850s introducing the "Bier Halle" (Butterfield 1968:21) to the area. French immigrants added artists and artisans to the culture of the city. Later immigrants to the area included Polish, Italians, 
Greeks, and Syrians, and in 1910, Chinese, all of which formed small communities within the city of San Antonio.

Culture and architecture from each immigrant community have seeped into San Antonio and merged together, forming a rich cultural community. This diverse culture is evident as you observe historic missions and Victorian mansions built next to modern offices and homes (Butterfield 1968; Jasinski 2020).

On March 2, 1861, Texas seceded from the Union and soon after the Civil War began. San Antonio was a Confederate storage area as well as a location to form military units; however, the city kept its distance from most of the fighting (Jasinski 2020).

After the Civil War, industries such as cattle, distribution, ranching, mercantile, gas and oil, and military centers in San Antonio prospered. The arrival of a railway transportation system in San Antonio in 1877 inspired economic growth throughout the city (Jasinski 2020; House 1949). Modernization increased dramatically between the 1880 s and the 1890 s, compared to the rest of the United States. Civic government, utilities, electric lights and street railways, street paving and maintenance, water supply, telephones, hospitals, and a power plant were all established or planned around this time (Butterfield 1968; Jasinski 2020).

\section{0 to 1950}

In 1921, a disastrous flood engulfed Houston and St. Mary's Street with approximately 9 feet of water. The Olmos Dam was built in response to this event to prevent further flooding, as well as the straightening and widening of sections of the San Antonio River. Another recommendation was to construct an underground channel in downtown San Antonio and covering portions of the river with concrete. This last idea upset many people, but eventually the compromise was reached in creating a Riverwalk with shops and restaurants. Construction of this Riverwalk was completed in 1941 (House 1949).

As the United States entered into World War II, San Antonio became an important military center and other city activities and construction ceased for nearly five years. Fort Sam Houston, and Kelly, Randolph, Brooks, and Lackland Air Force bases are all active military training centers today (Heusinger 1951).

Tourism is one of San Antonio's most important industries, drawing tens of thousands of visitors every year. More recent features include theme parks, zoos, museums, gardens, parks, and sporting attractions. The Riverwalk, also known as the Paseo del Rio, consists of over 2.5 miles of shops and restaurants as well as a boat ride along the channel. This is one of San Antonio's most visited attractions.

San Antonio Missions National Historical Park includes Mission Concepción (1731), Mission San José (1720), Mission San Juan Capistrano (1731), and Mission San Francisco de la Espada (1741). The Alamo (Mission San Antonio de Valero) in addition to the four previously mentioned Spanish Colonial missions also comprise the UNESCO World Heritage Site. Additionally, San Fernando Cathedral (1758), the Spanish Governor's Palace (1749), the Quadrangle at Fort Sam Houston (1878), and the Bexar County Courthouse (1891) are visited due to their interesting architecture.

\section{BACKGROUND AND HISTORIC MAP REVIEW}

SWCA performed a cultural resources background review on February 20, 2020, to determine if the Project area has been previously surveyed for cultural resources or if any cultural resources have been 
recorded within or near the Project area. To conduct this review, an SWCA archaeologist reviewed the relevant USGS 7.5-minute topographic quadrangle maps on the THC's Texas Historic Sites Atlas (Atlas) online-restricted archaeological sites database, as well as cemetery locations on Find A Grave's online database and historically relevant locations listed on the Texas Freedom Colonies database (THC 2020). These sources provided information on the nature and location of previously conducted archaeological surveys, previously recorded cultural resources sites, sites designated as State Antiquities Landmark (SALs), Official Texas Historical Markers (OTHMs), Recorded Texas Historic Landmarks, cemeteries, and local neighborhood surveys. To perform the historic map review, SWCA consulted historical USGS topographic maps available on USGS Topoview (USGS 2020). These sources contain information on potential historic resources and the general history of development in the Project area. Previous cultural resources investigations listed on the Atlas are limited to projects under purview of the ACT or the National Historic Preservation Act, as amended; therefore, the Atlas does not necessarily list all previous work conducted within a specific area. In addition, completed projects under these regulations may not be posted to the Atlas due to a delay between the completion of field work and the completion of reports.

The background literature review determined that the Project area has not been previously surveyed for cultural resources, and three cultural resources investigations, as well as three previously recorded cultural resources, occurred within a 1.0-mile $(1.6-\mathrm{km})$ radius of the Project area (Tables 1 and 2; Figure 4). In 1977, a linear survey northwest of the Project area identified no new cultural resources within the background review area (THC 2020). In 1991, a linear survey east of the Project area identified no new cultural resources within the background review area (THC 2020). In 2008, Raba-Kistner Consultants, Inc. conducted an area survey southwest of the Project area and identified one multicomponent archaeological site (i.e., 41BX1791). Site 41BX1791 is an unknown prehistoric lithic scatter and historic site with no diagnostic artifacts or structures and was determined not eligible for National Register of Historic Places (NRHP) / SAL listing (THC 2020). In 2011, Abasolo Archaeological Consultants recorded site 41BX1885. Site 41BX1885 is an unknown prehistoric lithic scatter site with no diagnostic artifacts and was determined not eligible for NRHP / SAL listing (THC 2020). Site 41BX487 is a multicomponent site with one diagnostic lithic projectile point and historic artifacts. The eligibility of site 41BX487 for NRHP / SAL listing is unknown and no additional information is provided (THC 2020).

SWCA also reviewed the Nationwide Environmental Title Research LLC (NETR 2020) Historic Aerials, Texas Freedom Colonies Project Atlas (2020), and Stoner Map System maps dating from 1836 to 1940 to determine if any potential historic-age resources were located within the Project area. Based on historical aerials, the Project area was predominantly a rural setting until the land was cleared in 1986 for the construction of the medical plaza (NETR 2020).

Table 1. Previously Conducted Cultural Resource Investigations Within a 1-Mile Radius of the Project Area

\begin{tabular}{llllllll}
\hline $\begin{array}{l}\text { Location } \\
\text { Related to } \\
\text { Project Area }\end{array}$ & $\begin{array}{l}\text { ACT } \\
\text { Permit } \\
\text { No. }\end{array}$ & $\begin{array}{l}\text { Project } \\
\text { Type }\end{array}$ & $\begin{array}{l}\text { Fieldwork } \\
\text { Date }\end{array}$ & $\begin{array}{l}\text { Report } \\
\text { Date }\end{array}$ & $\begin{array}{l}\text { Sponsoring } \\
\text { Agency }\end{array}$ & $\begin{array}{l}\text { Investigating } \\
\text { Firm }\end{array}$ & Additional Information \\
\hline $\begin{array}{l}0.58 \mathrm{mi}(0.93 \\
\mathrm{km}) \text { northwest }\end{array}$ & - & $\begin{array}{l}\text { Linear } \\
\text { Survey }\end{array}$ & 1977 & - & $\begin{array}{l}\text { Environmental } \\
\text { Protection } \\
\text { Agency }\end{array}$ & - & $\begin{array}{l}\text { No additional information } \\
\text { available on the Atlas } \\
\text { (THC 2020). }\end{array}$ \\
\hline $\begin{array}{l}0.75 \mathrm{mi}(1.21 \\
\mathrm{km}) \text { east }\end{array}$ & - & $\begin{array}{l}\text { Linear } \\
\text { Survey }\end{array}$ & 1991 & - & $\begin{array}{l}\text { Federal } \\
\text { Highway } \\
\text { Administration }\end{array}$ & - & $\begin{array}{l}\text { No additional information } \\
\text { available on the Atlas } \\
\text { (THC 2020). }\end{array}$ \\
\hline $\begin{array}{l}0.57 \text { mi }(0.91 \\
\mathrm{km})\end{array}$ & 5031 & $\begin{array}{l}\text { Area } \\
\text { southwest }\end{array}$ & 2008 & - & $\begin{array}{l}\text { Texas } \\
\text { Department of } \\
\text { Transportation }\end{array}$ & $\begin{array}{l}\text { Raba-Kistner } \\
\text { Consultants, } \\
\text { Inc. }\end{array}$ & $\begin{array}{l}\text { No additional information } \\
\text { available on the Atlas } \\
\text { (THC 2020). }\end{array}$ \\
\hline
\end{tabular}




\section{Restricted Information}

\section{Not for Public Disclosure}

Figure 4. Project area in relation to known cultural resources. 
Cultural Resources Investigations for the University of Texas Health Science Center at San Antonio Project, Bexar County, Texas

Table 2. Previously Recorded Cultural Resources Within a 1-Mile Radius of the Project Area

\begin{tabular}{|c|c|c|c|}
\hline $\begin{array}{l}\text { Location } \\
\text { Related to } \\
\text { Project Area }\end{array}$ & Site & Site Type & Resource Description \\
\hline $\begin{array}{l}0.23 \text { mile } \\
(0.36 \mathrm{~km}) \\
\text { northeast }\end{array}$ & 41BX1885 & Prehistoric & $\begin{array}{l}\text { Abasolo Archaeological Consultants observed a } \\
\text { prehistoric lithic scatter. Cultural materials observed } \\
\text { include flakes, cores, and bifacial fragments (THC 2020). }\end{array}$ \\
\hline $\begin{array}{l}0.63 \text { mile } \\
(1.01 \mathrm{~km}) \\
\text { southwest }\end{array}$ & 41BX1791 & Multicomponent & $\begin{array}{l}\text { Raba-Kistner Consultants, Inc. recorded a multicomponent } \\
\text { site with no diagnostic artifacts observed. The prehistoric } \\
\text { component consists of a lithic scatter with utilized flakes, } \\
\text { scrapers, and burned rock. The historic component } \\
\text { consists of an iron horseshoe, washer, and five embedded } \\
\text { concrete slabs (THC 2020). }\end{array}$ \\
\hline $\begin{array}{l}0.97 \text { mile } \\
(1.57 \mathrm{~km}) \\
\text { south- } \\
\text { southwest }\end{array}$ & $41 \mathrm{~B} \times 487$ & Multicomponent & $\begin{array}{l}\text { Site } 41 \mathrm{BX} 487 \text { is a multicomponent site. The prehistoric } \\
\text { component consists of a lithic scatter, scrapers, preforms, } \\
\text { bifaces, perforators, burned rocks, and one projectile point. } \\
\text { The historic component consists of bottles, knives, and a } \\
\text { button (THC 2020). }\end{array}$ \\
\hline
\end{tabular}

\section{FIELD METHODS}

SWCA's investigations consisted of construction monitoring of the Project area activities. A qualified SWCA archaeologist examined the ground surface and construction exposures for cultural resources. The archaeologists coordinated all field activities with appropriate personnel and any on-site construction foreman regarding scheduling and safety. The archaeologist complied with all applicable Occupational Safety and Health Administration safety regulations and wore all required safety equipment (e.g. hardhat, safety glasses, and steel-toed boots). Monitoring consisted of a qualified archaeologist observing the excavation process, examining sediment as it was removed from each trench, periodic sampling of backhoe bucket excavations (i.e., screening of every fifth bucket), and examining the side walls and spoils for cultural materials. Backhoe trenches (BHTs) are generally excavated in 20-foot-long (6-m-long) segments, measuring approximately 3 feet $(1 \mathrm{~m})$ wide to a maximum depth not exceeding 4.0 feet $(1 \mathrm{~m})$.

SWCA conducted a primarily non-collection survey; artifacts, if encountered, were to be examined, quantified, and assessed as to age and origin, and not collected unless temporally diagnostic artifacts dating prior to 1870 were encountered. Temporally diagnostic artifacts, if present, were to be collected, described in detail, photographed, and curated at the CAR-UTSA. Following the review and acceptance of the final cultural resources report, all records, photographs, and diagnostic artifacts will be curated with CAR-UTSA, in accordance with the CTA guidelines, per requirements of the ACT.

\section{MONITORING RESULTS}

SWCA conducted monitoring investigations for the 0.28-acre (0.1-ha) Project area from April 7-14, 2020 (Figure 5). The primary purpose of this investigation was to identify and evaluate cultural resource sites. SWCA archaeologists visually examined the Project area and documented an urban setting with a developed medical center situated south of Floyd Curl Drive, bounded by Zarzamora Creek to the west, a parking lot to the east, and the UTHSCSA building to the south (Figures 6-8). 


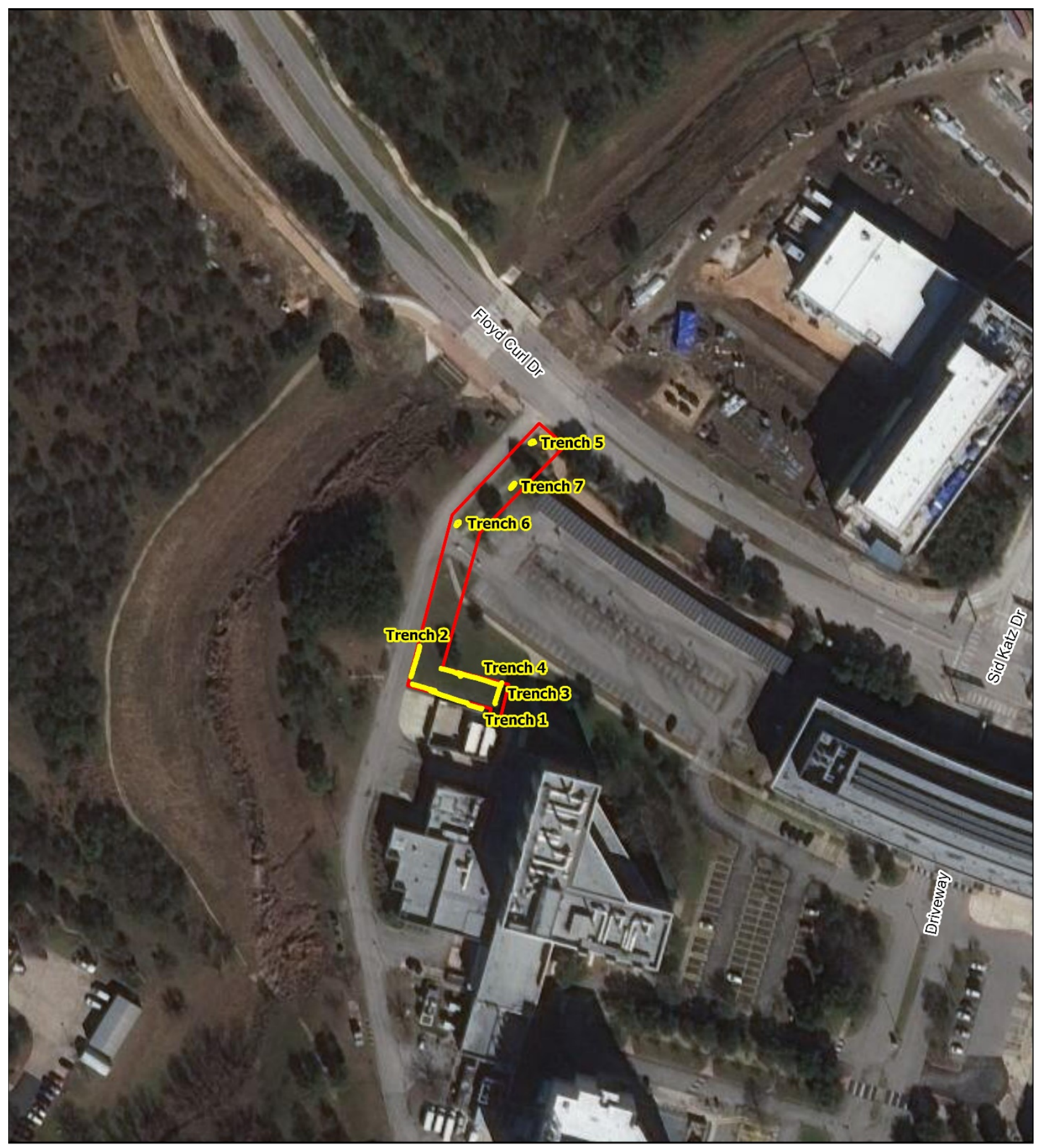

\begin{tabular}{|c|c|c|c|}
\hline $\mathrm{CA}_{1}$ & \begin{tabular}{|c} 
UTHSCSA - \\
TRILEAF CORPORATION \\
MONITORING RESULTS
\end{tabular} & $\begin{array}{l}\text { Project Area } \\
\text { Trench Location }\end{array}$ & $1: 2,000$ \\
\hline ENVIRONMENTAL CONSULTANTS & BEXAR COUNTY, TEXAS & & $=\frac{100}{25}-{ }_{50}^{0}{ }^{\text {Meters }}{ }^{200}$ \\
\hline
\end{tabular}

Figure 5. Project area monitoring results. 


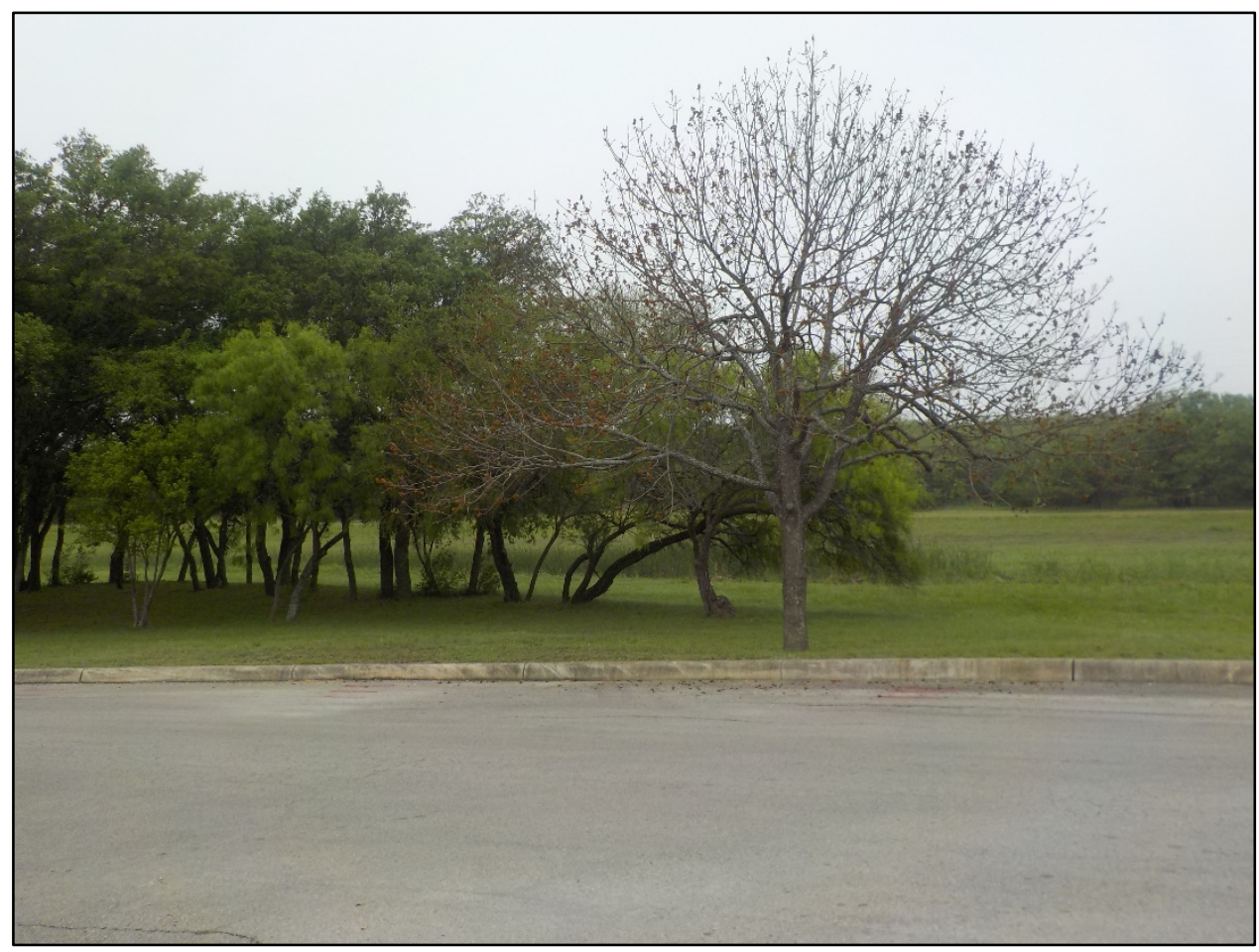

Figure 6. Overview of Zarzamora Creek in background identified by tall grasses, facing west.

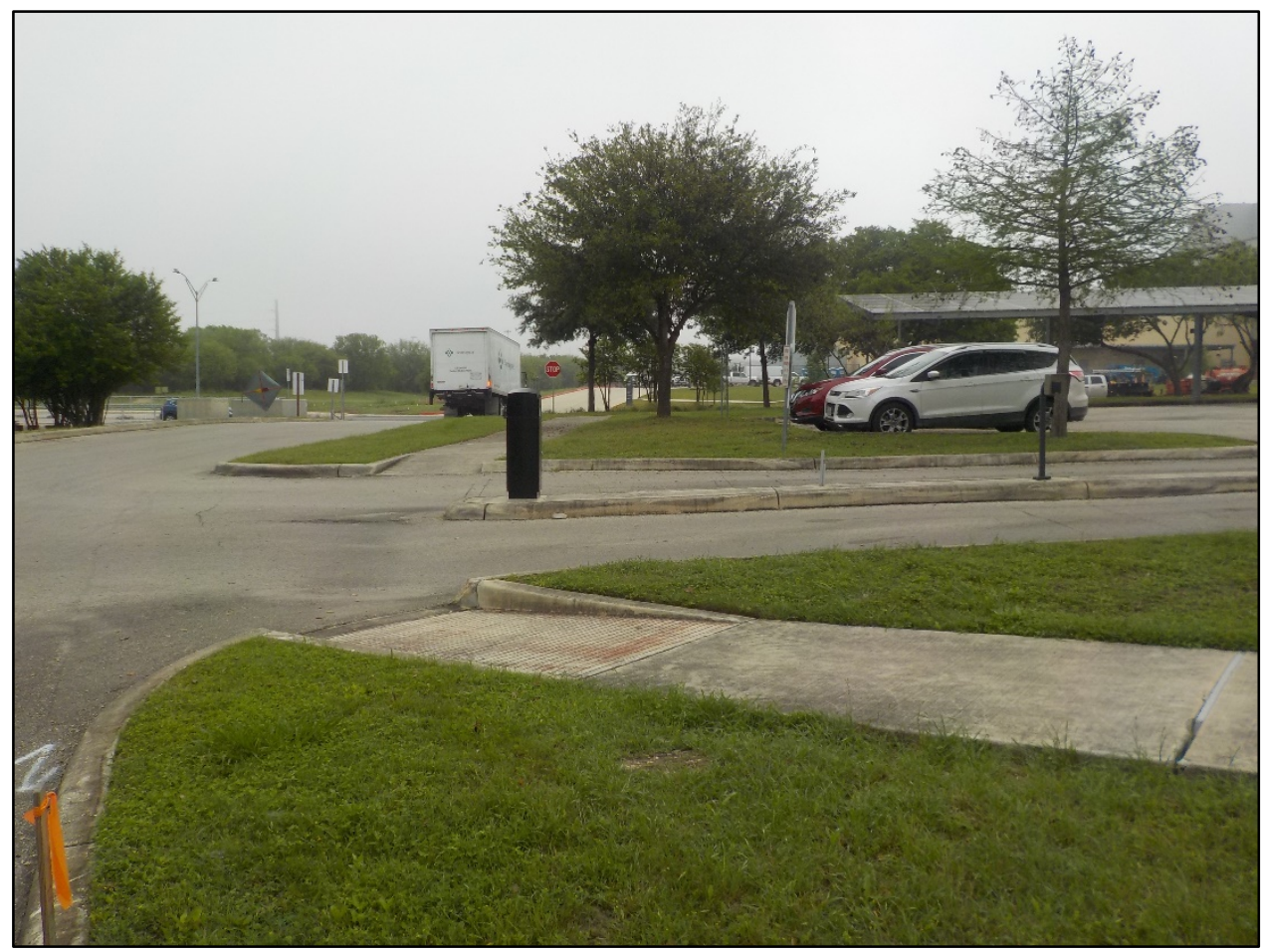

Figure 7. Overview of Project area locations of Trenches 5-7 prior to construction, view facing north toward Floyd Curl Drive. 


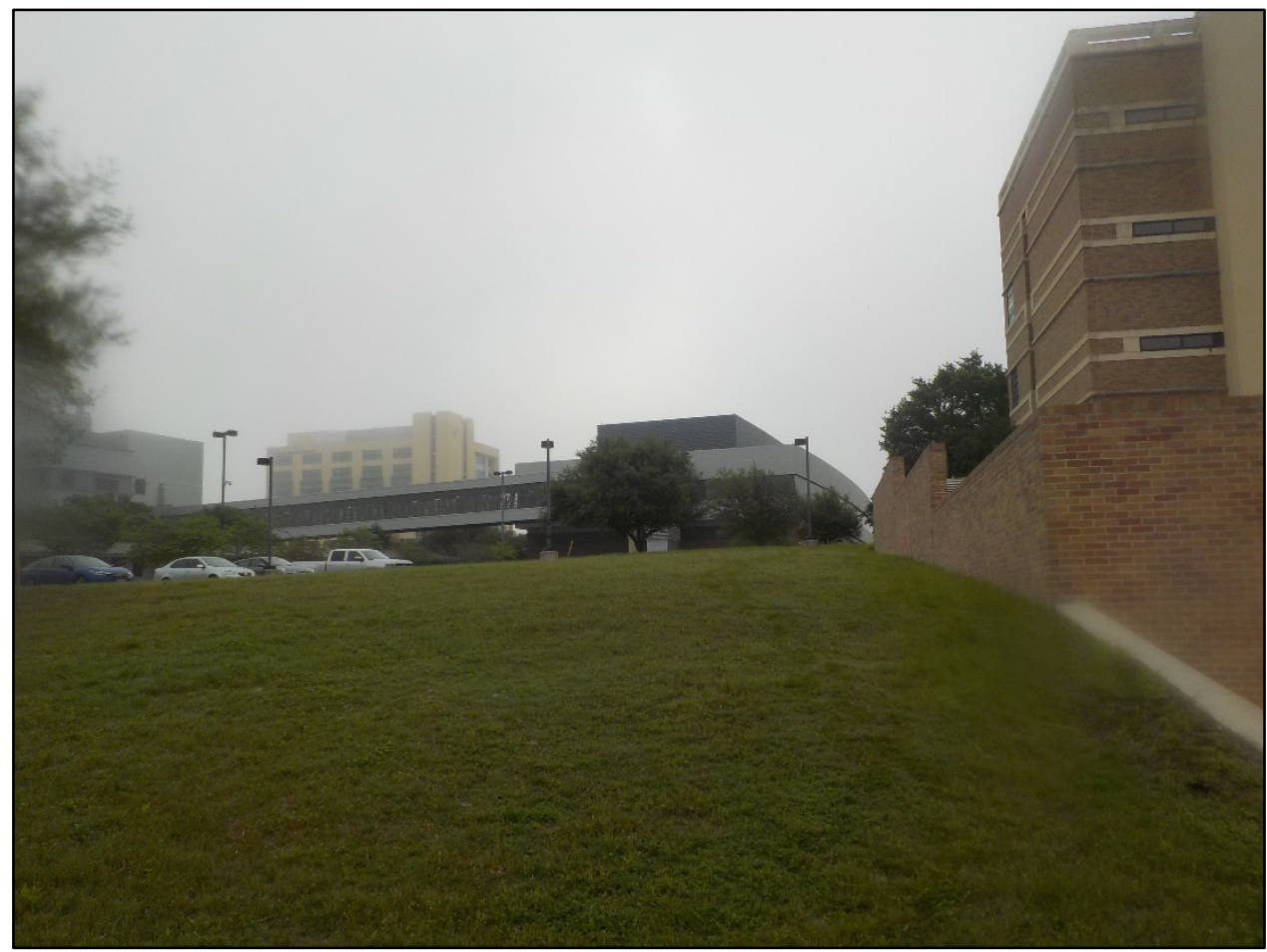

Figure 8. UTHSCSA building to right of frame and overview of Project area as well as locations of Trenches 1-4 prior to construction, view facing east.

The vegetation within the Project area consists of landscaped grasses and planted trees with mesquite, oak, and grasses aligning the Zarzamora Creek to the west. Previous impacts and disturbances to the Project Area include utility, road, and parking lot construction, as well as commercial development.

Subsurface monitoring investigations occurred at seven trench locales (i.e., Trenches 1-7) within the Project area (see Figure 5). The BHTs for this Project varied greatly in length extending from 6.6 feet (2 $\mathrm{m})$ to 82 feet $(25 \mathrm{~m})$ with a maximum depth of 3.75 feet $(1.1 \mathrm{~m})$ and a maximum width of 3.2 feet $(1 \mathrm{~m})$. During the excavation process, soils from the excavation were deposited adjacent to the trench opening (Figure 9). The SWCA archaeologist inspected spoils and trench profile walls for cultural materials during the excavation process to determine if any cultural deposits or features were exposed as well as screened every fifth bucket of excavated sediment.

SWCA observed shallow soil deposits overlaying degraded bedrock in Trenches 1-4 in the southern portion of the Project area (Figure 10). The typical soil profile observed within the southern portion of the Project area consisted of the following:

- 0 to 1.15 foot ( 0 to $0.35 \mathrm{~m}$ ): $10 \mathrm{YR} 3 / 1$ very dark gray clay loam, $10 \%$ mottles, limestone inclusion; and

- 1.15 foot to depth of trench ( $0.35 \mathrm{~m}$ to depth of trench): degraded limestone bedrock. 


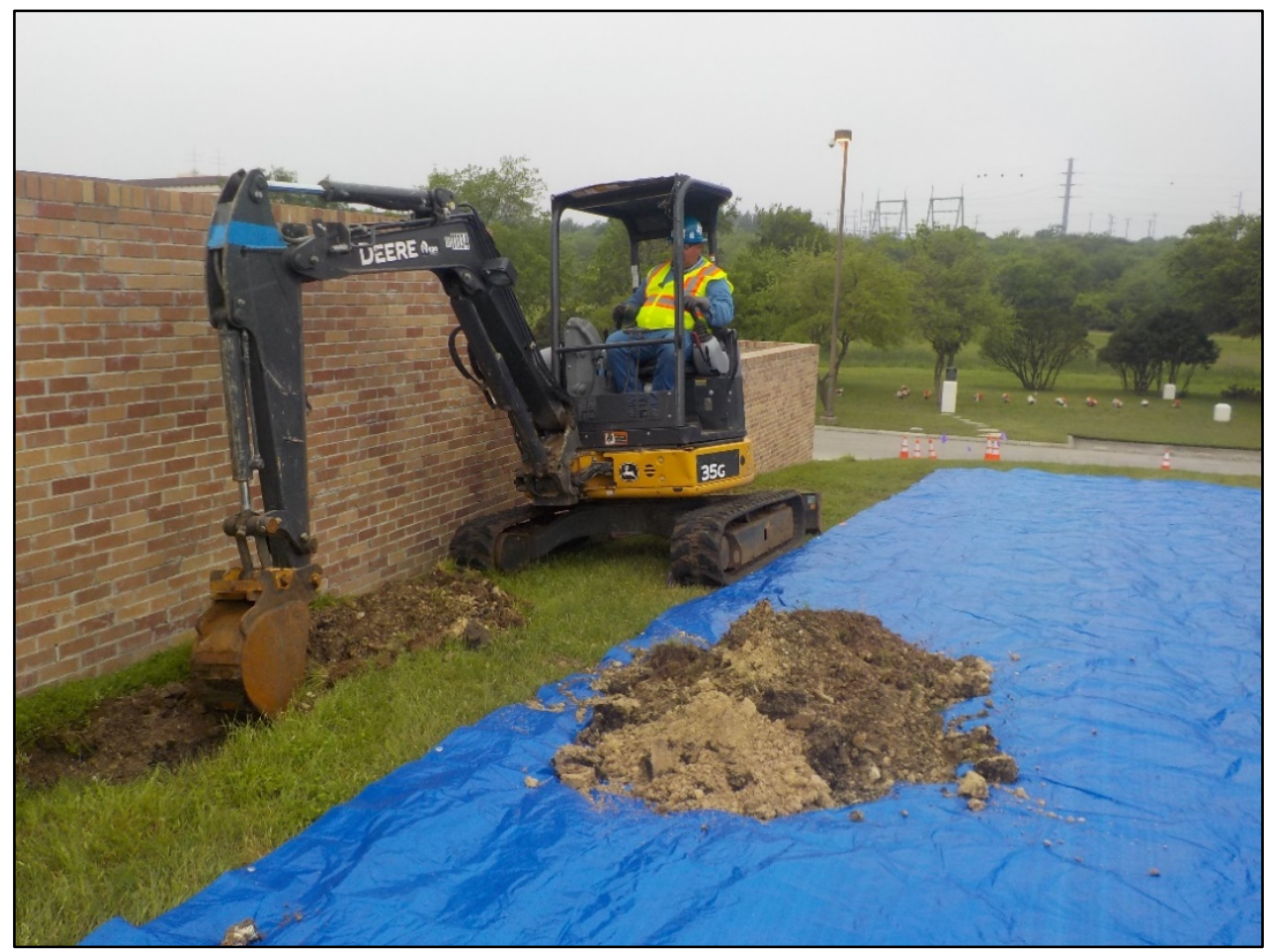

Figure 9. Overview of excavation process within the Project area at Trench 1 , view facing west.

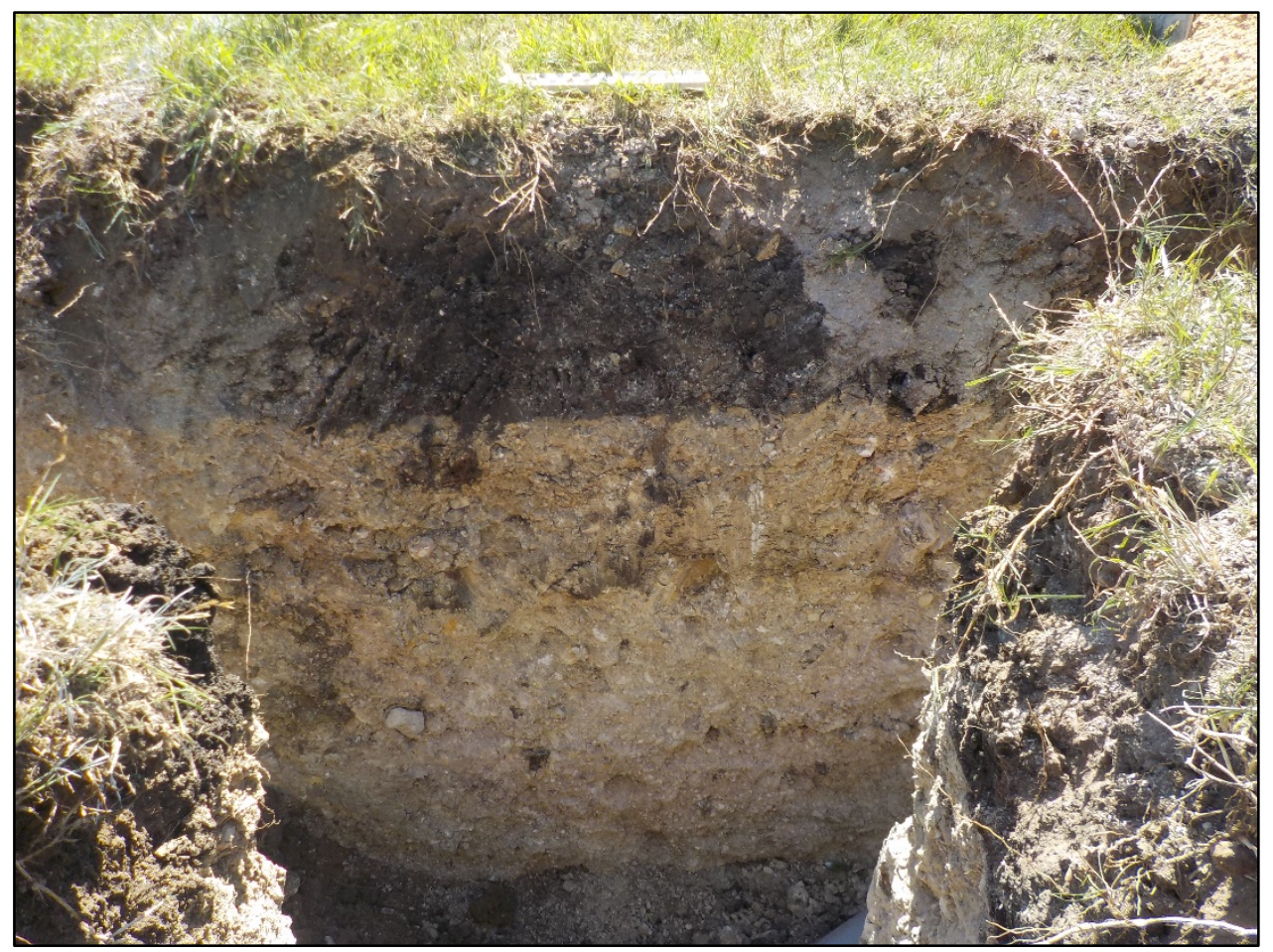

Figure 10. Overview of typical trench profile for Trenches 1-4 demonstrating shallow soil deposits within the southern portion of Project area at the intersection of Trench 3 and Trench 4, view facing north. 
SWCA observed moderately disturbed soils from the installation of utilities, road and walkways, and from artificial landscaping and associated irrigation lines within Trenches 5-7 in the northern portion of the Project area (Figure 11). The typical soil profile observed within the northern portion of the Project area consisted of the following:

- 0 to 2.6 foot ( 0 to $0.80 \mathrm{~m}$ ): 10 YR $4 / 2-2 / 2$ dark grayish brown clay loam, $>25 \%$ fill inclusions;

- 2.6 to 3.3 foot (0.8 to $1.0 \mathrm{~m}$ ): 10YR 2/1 black clay; and

- 3.3 foot to depth of trench (1.0 m to depth of trench): 10YR 4/1 dark gray basal clay (Figure 12).

Overall, no cultural materials, intact archaeological deposits, or archaeological features were observed during the excavations.

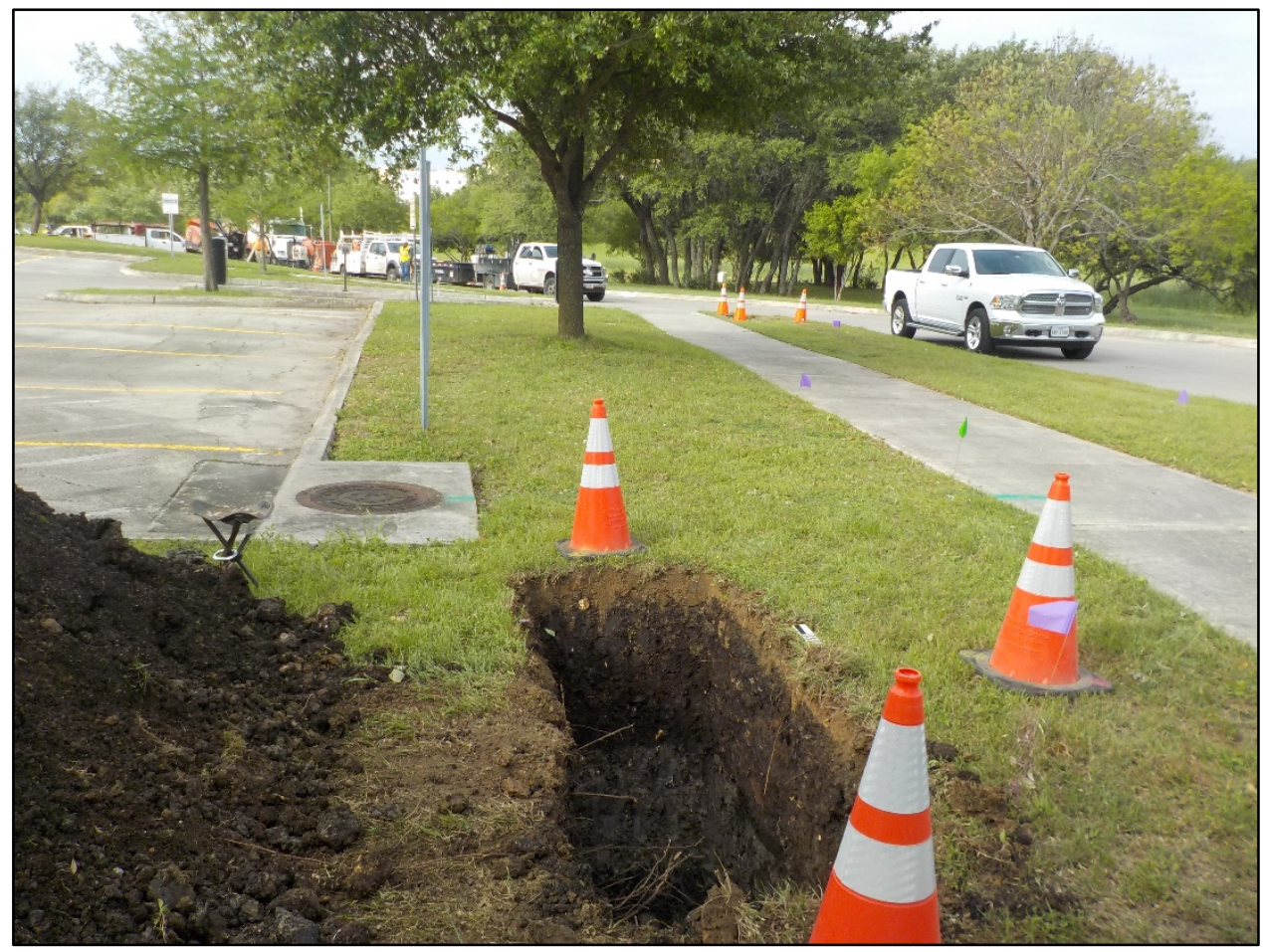

Figure 11. Overview of Trench 7 locale and surrounding disturbances within the Project area, view facing south.

\section{SUMMARY AND RECOMMENDATIONS}

At the request of TriLeaf, SWCA conducted a cultural resources investigation for UTHSCSA Project located in northwest San Antonio, Bexar County, Texas. The Project involves the installation of a 432foot-long (132-m-long) fiber-optic communication line directly south of Floyd Curl Drive, bounded by the UTHSCSA building to the south, a paved parking lot to the east, and Zarzamora Creek to the west. The total size of the proposed Project area measures approximately 0.28 acre $(0.1 \mathrm{ha})$. The proposed Project is located on land owned by the University of Texas, a political subdivision of the State of Texas, and is therefore subject to review by the THC under the ACT, as well as the Historic Preservation and Design Sections of the City of San Antonio's UDC (Article VI 35-630 to 35-634). 


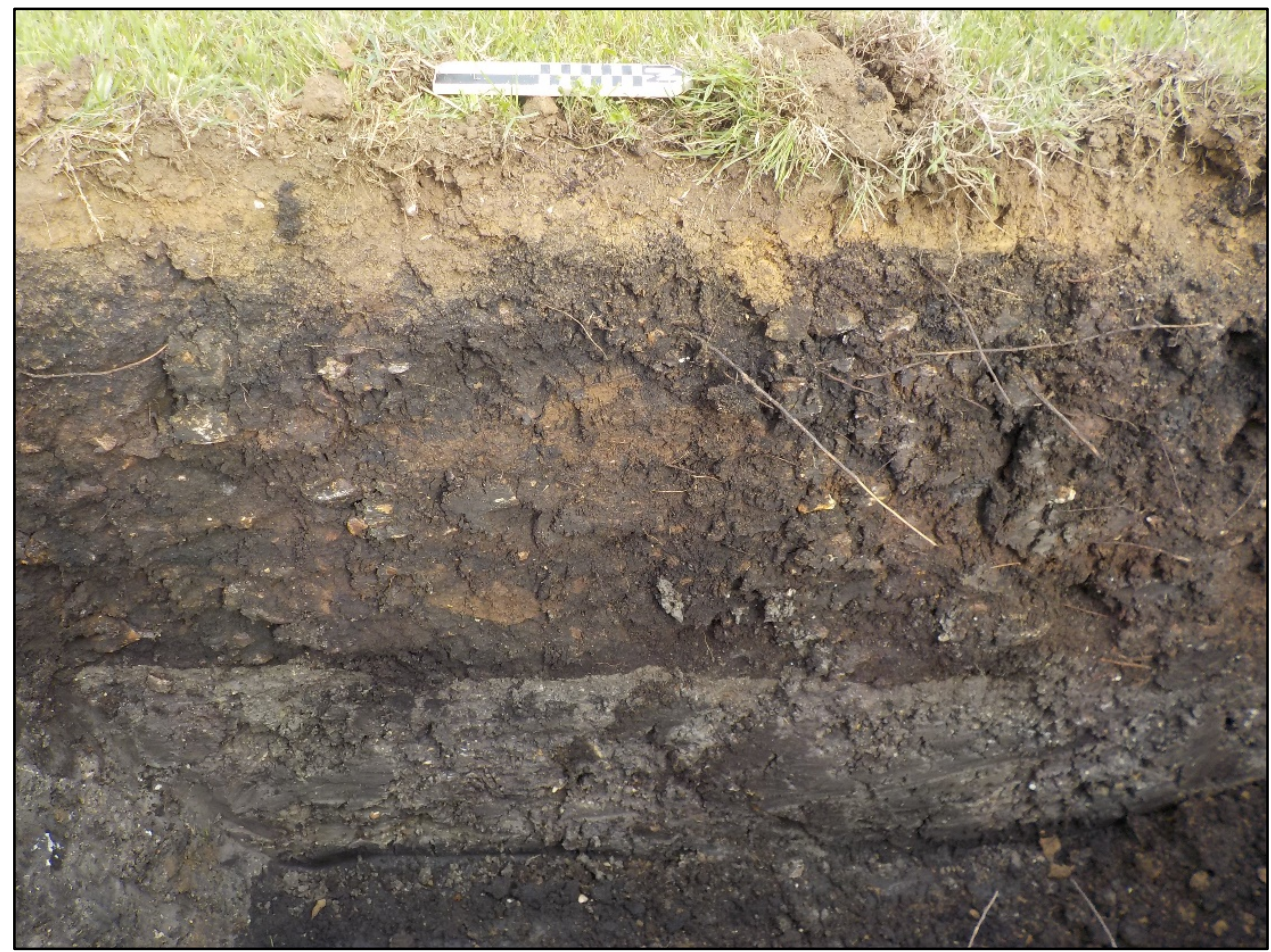

Figure 12. Overview of typical trench profile for Trenches 5-7 locale demonstrating disturbed soil over basal clay within the northern portion of the Project area, view facing west.

Consistent with the ACT, the purpose of the investigation was to identify and assess any cultural resources, such as historic and prehistoric archaeological sites, historic buildings, structures, objects, and sites (such as cemeteries) that might be located within the boundaries of the proposed Project area, and evaluate the significance and eligibility of these cultural resources for designation as a SALs under the ACT. All investigations were conducted in accordance with the standards and guidelines established by the THC and CTA under ACT Permit No. 9311.

Investigations included a background literature and historic map review, and monitoring of mechanical trench excavations within the Project area to determine the presence, extent, and potential significance of deeply buried archaeological sites. The background review determined that the Project area has not been previously surveyed for cultural resources, and three cultural resources investigations as well as three previously recorded cultural resources occurred within a 1.0-mile (1.6-km) radius of the Project area. Based on historical aerials, the Project area was predominantly a rural setting until the land was cleared in 1986 for the construction of the medical plaza.

An SWCA archaeologist conducted cultural resources monitoring from April 7-14, 2020. Previous impacts and disturbances to the Project area includes extensive development associated with the medical plaza consisting of road and walkway construction, utility installation, and artificial landscaping and associated irrigation lines within the Project area and documented during the investigation. SWCA did not encounter subsurface cultural materials, intact archaeological features or temporally diagnostic artifacts within the Project area. In accordance with the ACT and the UDC, SWCA has made a reasonable and good faith effort to identify cultural resources properties within the Project area. No properties were identified within the Project area that may meet the criteria for listing as a SAL, nor as a Historic Landmark or District according to the UDC. Therefore, SWCA recommends that no additional cultural resources investigations are warranted within the UTHSCSA Project area, as currently defined. 


\section{REFERENCES CITED}

Barr, A.

2020 Handbook of Texas Online, Siege of Bexar. Available at:

https://tshaonline.org/handbook/online/articles/qeb01. Accessed April 20, 2020.

Barnes, V. E., Shell Development Co., Amerada Petroleum Corp., T.E. Brown, N.B. Waechter, and R.L. Dillon

1983 Geologic Atlas of Texas. Bureau of Economic Geology. The University of Texas at Austin.

Bever, M. R. and D. J. Meltzer

2007 Exploring Variation in Paleoindian Live Ways: The Third Revised Edition of the Texas Clovis Fluted Point Survey. Bulletin of the Texas Archeological Society 78:65-99.

Black, S. L.

1989 Environmental Setting. In From the Gulf to the Rio Grande: Human Adaptation in Central, South, and Lower Pecos Texas, by Thomas R. Hester, Stephen L. Black, D. Gentry Steele, Ben W. Olive, Anne A. Fox, Karl J. Reinhard, and Leland C. Bement, pp. 5-16. Research Series No. 33. Arkansas Archeological Survey, Fayetteville.

Black, S. L., and A. J. McGraw

1985 The Panther Springs Creek Site: Cultural Change and Continuity within the Upper Salado Creek Watershed, South-Central Texas. Archeological Survey Report No. 100. Center for Archeological Research, The University of Texas at San Antonio.

Black, S. L., L. W. Ellis, D. G. Creel, and G. T. Goode 1997 Hot Rock Cooking on the Greater Edwards Plateau: Four Burned Rock Midden Sites in West Central Texas. 2 vols. Studies in Archeology 22, Texas Archeological Research Laboratory, The University of Texas at Austin. Archeology Studies Program Report 2, Environmental Affairs Division, Texas Department of Transportation, Austin.

Blair, W. F.

1950 The Biotic Provinces of Texas. The Texas Journal of Science. 2(1):93-117.

Bousman, C. B.

1998 Paleoenvironmental Change in Central Texas: The Palynological Evidence. Plains Anthropologist 43(164):201-219.

Bousman, C. B., B. W. Baker, and A. C. Kerr

2004 Paleoindian Archeology in Texas. In The Prehistory of Texas. Edited by Timothy K. Perttula, pp. 15-97. Texas A\&M University Press, College Station.

Burt, W. H., and R. P. Grossenheider

1976 Peterson Field Guides: Mammals. Third Edition. Houghton Mifflin Company, Boston and New York.

Butterfield, J. C.

1968 The Free State of Bejar. 2nd ed. Library Committee The Daughters of the Republic of Texas at the Alamo, Texas. 
Caldwell, L.

2020 Handbook of Texas Online. Casas Revolt. Available at:

https:/tshaonline.org/handbook/online/articles/jcc02. Accessed April 20, 2020.

Chipman, Donald E.

1992 Spanish Texas, 1519-1821. The University of Texas Press, Austin.

Collins, M. B.

1968 A Note on the Broad Corner-Notched Projectile Points Used In Bison Hunting in Western Texas. The Bull Roarer 3(2) 13-14. The University of Texas Anthropology Society, Department of Anthropology, The University of Texas at Austin.

1990 The Archeological Sequence at Kincaid Rockshelter, Uvalde County, Texas. Transactions of the Twenty-Fifth Regional Archeological Symposium for Southeastern New Mexico and Western Texas, pp. 25-34.

1995 Forty Years of Archeology in Central Texas. Bulletin of the Texas Archeological Society $66: 361-400$.

1998 Early Paleoindian Components. In Wilson-Leonard: An 11,000-Year Archeological Record of Hunter-Gatherers in Central Texas, Volume I, edited and assembled by Michael B.

Collins, pp. 123-159. Studies in Archeology 31. Texas Archeological Research Laboratory, The University of Texas at Austin. Archeology Studies Program, Report 10. Environmental Affairs Division, Texas Department of Transportation.

2004 Archeology in Central Texas. In The Prehistory of Texas. Edited by Timothy K. Perttula, pp. 101-126. Texas A\&M University Press, College Station.

Collins, M. B., G. L. Evans, T. N. Campbell, M. C. Winans, and C. E. Mear

1989 Clovis Occupation at Kincaid Rockshelter, Texas. Current Research in the Pleistocene 6:3-4.

Collins, M. B., J. Guy, and S. W. Dial

1998 The Archaic Period, 8800 to 1300 B.P. In Wilson-Leonard: An 11,000-Year Archeological Record of Hunter-Gatherers in Central Texas, Volume I, edited and assembled by Michael B. Collins, pp. 211-270. Studies in Archeology 31. Texas Archeological Research Laboratory, The University of Texas at Austin. Archeology Studies Program, Report 10. Environmental Affairs Division, Texas Department of Transportation.

Collins, M. B., T. R. Hester, and P. J. Hedrick

1992 Engraved Cobbles from the Gault Site, Central Texas. Current Research in the Pleistocene $9: 3-4$.

Collins, Michael B., Dale B. Hudler, and Steve L. Black

2003 Pavo Real (41BX52): A Paleoindian and Archaic Camp and Work-Shop on the Balcones Escarpment, South-Central Texas. Studies in Archeology No. 41, Austin: Texas Archeological Research Laboratory, University of Texas and Texas Department of Transportation, Environmental Affairs Division, Archeology Studies Program, Report 50, Austin, Texas.

Conant, R., and J. T. Collins

1998 Peterson Field Guides: Reptiles and Amphibians Eastern and Central North America. Third Edition. Houghton Mifflin Company, Boston and New York. 
Correll, D. S., and M. C. Johnston

1979 Manual of the Vascular Plants of Texas. University of Texas at Dallas.

Davis, W. B., and D. J. Schmidly

1994 The Mammals of Texas. University of Texas Press, Austin.

Dibble, D. S., and D. Lorrain

1968 Bonfire Shelter: A Stratified Bison Kill Site, Val Verde County, Texas. Miscellaneous Papers

No. 1. Texas Memorial Museum, The University of Texas at Austin.

Fehrenbach, T.R.

1978 Lone Star: A History of Texas and the Texans. Macmillan. New York.

Gould, F. W.

1969 Texas Plants: A Checklist and Ecological Survey. Texas Agricultural Extension Service, Texas A\&M University, College Station.

Griffith, G. E., S. A. Bryce, J. M. Omernik, J. A. Comstock, A. C. Rogers, B. Harrison, S. L. Hatch, and D. Bezanson

2007 Ecoregions of Texas (color poster with map, descriptive text, and photographs). Map scale 1:2,500,000. Reston, Virginia, U.S. Geological Survey.

Groneman, B.

2001 Eyewitness to the Alamo. Revised ed. Republic of Texas Press, Texas.

Hatch, T.

1999 Encyclopedia of the Alamo and the Texas Revolution. McFarland \& Company, Inc.,

Publishers, Jefferson, North Carolina.

Hester, T. R.

2004 Prehistory of South Texas. In The Prehistory of Texas. Edited by Timothy K. Perttula, pp. 127-154. Texas A\&M University Press, College Station.

Heusinger, E. W., F.R.G.S.

1951 A Chronology of Events in San Antonio: Being a Concise History of the City Year By Year: From the Beginning of its Establishment to the End of the First Half of the Twentieth Century. Standard Printing Co., San Antonio, Texas.

Houk, B. A., K. A. Miller, and E. R. Oksanen

2008 The Gatlin Site (41KR621): Investigating Archaic Lifeways on the Southern Edwards Plateau of Central Texas. Texas Department of Transportation Archeological Studies Program No. 108, SWCA Cultural Resources Report No. 149, SWCA Environmental Consultants, Austin.

House, B.

1949 City of Flaming Adventure: The Chronicle of San Antonio. The Naylor Company, San Antonio, Texas.

Huebner, J. A.

1991 Late Prehistoric Bison Populations in Central and South Texas. Plains Anthropologist 36(137):343-358. 
Huffines, A. C.

1999 The Blood of Noble Men: An Illustrated Chronology of the Alamo Siege and Battle. Eakin Press, Austin, Texas.

Jasinski, L. E.

2020 Handbook of Texas Online, San Antonio, TX. Available at: https://tshaonline.org/handbook/ online/articles/hds02. Accessed April 20, 2020.

Jelks, E. B.

1962 The Kyle Site: A Stratified Central Texas Aspect Site in Hill County, Texas. Archaeology Series No. 5. Department of Anthropology, The University of Texas at Austin.

Johnson, L.

1995 Past Cultures and Climates at Jonas Terrace: 41 ME29 of Medina County, Texas. Report No. 40. Office of the State Archeologist, Texas Historical Commission, Austin

Johnson, L, and G. T. Goode

1994 A New Try at Dating and Characterizing Holocene Climates, as well as Archeological Periods, on the Eastern Edwards Plateau. Bulletin of the Texas Archeological Society 65:151.

Johnson, L, Jr., D. A. Suhm, and C. D. Tunnell

1962 Salvage Archeology of Canyon Reservoir: The Wunderlich, Footbridge, and Oblate Sites. Bulletin No. 5. Texas Memorial Museum, The University of Texas at Austin.

Johnston, L. C.

1947 San Antonio St. Anthony's Town. Librarian's Council, San Antonio, Texas

Kelley, J. C., and T. N. Campbell

1942 What are the Burnt Mounds of Texas? American Antiquity 7(3):319-322.

Kibler, K. W., and A. M. Scott

2000 Archaic Hunters and Gatherers of the Balcones Canyonlands: Data Recovery Excavations at the Cibolo Crossing Site (41BX377), Camp Bullis Military Reservation, Bexar County, Texas. Reports of Investigations No. 126. Prewitt and Associates, Inc., Austin.

Kleinbach, K., G. Mehalchick, J. T. Abbott, and J. M. Quigg

1995 Other Analyses. In NRHP Significance Testing of 57 Prehistoric Archeological Sites on Fort Hood, Texas, Volume II, edited by James T. Abbott and W. Nicholas Trierweiler, pp. 765842. Archeological Resource Management Series, Research Report No. 34. United States Army Fort Hood.

Kutac, Edward A., and S. Christopher Caran

1994 Birds and Other Wildlife of South Central Texas. University of Texas, Austin.

McKinney, W. W.

1981 Early Holocene Adaptations in Central and Southwestern Texas: The Problem of the Paleoindian-Archaic Transition. Bulletin of the Texas Archeology Society 52:91-120.

Meltzer, D. J., and M. R. Bever

1995 Paleoindians of Texas: An Update on the Texas Clovis Fluted Point Survey. Bulletin of the Texas Archeological Society 66:47-81. 
Nationwide Environmental Title Research (NETR)

2020 Historic Aerials Map Viewer, Nationwide Environmental Title Research, LLC. Available at: https://www.historicaerials.com/viewer. Accessed on April 20, 2020.

Natural Resources Conservation Service (NRCS)

2020 Web Soil Survey. U.S. Department of Agriculture. Available at: http://websoilsurvey.nrcs.usda.gov. Accessed April 20, 2020.

Oksanen, E. R.

2008 Archaeological Investigations at the Icehouse Site, 41HY161: A Reevaluation of Early Archaic Technology, Subsistence and Settlement Along the Balcones Escarpment and Central Texas. Unpublished Master's Thesis, Department of Anthropology, Texas State University, San Marcos.

Petrides, G. A.

1988 Peterson Field Guides: A Guide to Eastern Trees. Houghton Mifflin Company, Boston and New York.

Prewitt, E. R.

1981 Cultural Chronology in Central Texas. Bulletin of the Texas Archeological Society 52:65-89.

1985 From Circleville to Toyah: Comments on Central Texas Chronology. Bulletin of the Texas Archeological Society 54:201-238.

Ramsdell, C.

1968 Special Supplement to the Hemisfair Edition of San Antonio: A Historical and Pictorial Guide. University of Texas Press, Austin, Texas.

Schmidly, D. J.

1983 Texas Mammals East of the Balcones Fault Zone. Texas A\&M Press, College Station.

Schoelwer, S. P.

2020 Handbook of Texas Online, s.v. Mission San Antonio de Valero. Available at:

https:/tshaonline.org/handbook/online/articles/uqs08. Accessed April 20, 2020.

Shafer, H. J.

1963 Test Excavations at the Youngsport Site: A Stratified Terrace Site in Bell County, Texas. Bulletin of Texas Archeological Society 34: 57-81.

Simpson, B. J.

1988 A Field Guide to Texas Trees. Texas Monthly Field Guide Series. Texas Monthly Press, Austin, Texas.

Sorrow, W. M.

1969 Archeological Investigations at the John Ischy Site: A Burned Rock Midden in Williamson County, Texas. Papers of the Texas Archeological Salvage Project No. 18. The University of Texas at Austin.

Story, D. A.

1985 Adaptive Strategies of Archaic Cultures of the West Gulf Coastal Plain. In Prehistoric Food Production in North America, edited by R. I. Ford, pp. 19-56. Anthropological Papers 75. Museum of Anthropology, University of Michigan, Ann Arbor. 
Texas Freedom Colonies Project

2020 Texas Freedom Colonies Project Atlas and Study database, Dr. Andrea Roberts, Texas A\&M University. Available at: http://www.thetexasfreedomcoloniesproject.com/. Accessed April 20, 2020.

Texas Historical Commission (THC)

2020 Texas Archeological Sites Atlas restricted database, Texas Historical Commission. Available at http://nueces.thc.state.tx.us/. Accessed April 20, 2020.

Thoms, A. V., D. D. Kuehn, B. W. Olive, J. E. Dockall, P. A. Clabaugh, and R. Mandel

1996 Early and Middle Holocene Occupations at the Richard Beene Site: The 1995 Southern Texas Archaeological Association Field School Project. La Tierra 23(4):8-36.

Thoms, A. V., and R. D. Mandel

1992 The Richard Beene Site: A Deeply Stratified Paleoindian to Late Prehistoric Occupation in South-Central Texas. Current Research in the Pleistocene 9:42-44.

Toomey III, R. S., M. D. Blum, and S. Valastro Jr.

1993 Late Quaternary Climates and Environments of the Edwards Plateau, Texas. Global and Planetary Change 7:299-320.

U.S. Geological Survey (USGS)

2020 TopoView: historical topographic map collection. Published by the U.S. Geological Survey (USGS). Available at: http://ngmdb.usgs.gov/maps/TopoView. Accessed April 20, 2020.

Wandsnider, L.

1997 The Roasted and the Boiled: Food Composition and Heat Treatment with Special Emphasis on Pit-Hearth Cooking. Journal of Anthropological Archaeology 16:1-48.

Weir, F. A.

1976 The Central Texas Archaic. Ph.D. dissertation, Department of Anthropology, Washington State University, Pullman.

Willey, G. R., and P. Phillips

1958 Method and Theory in American Archaeology. University of Chicago Press, Chicago.

Wilson, E. W.

1930 Burnt Rock Mounds of Southwest Texas. Bulletin of the Texas Archeological and Paleontological Society 2:59-63. 